\title{
Simulated oxygen isotopes in cave drip water and speleothem calcite in European caves
}

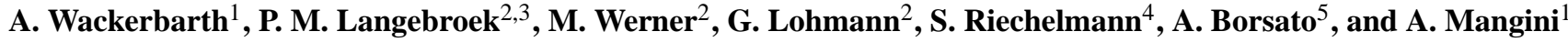 \\ ${ }^{1}$ Heidelberg Academy of Sciences, Heidelberg, Germany \\ ${ }^{2}$ Alfred Wegener Institute, Bremerhaven, Germany \\ ${ }^{3}$ Bjerknes Centre for Climate Research, Bergen, Norway \\ ${ }^{4}$ Ruhr-Universität Bochum, Bochum, Germany \\ ${ }^{5}$ Museo delle Scienze, Trento, Italy
}

Correspondence to: A. Wackerbarth (anne.wackerbarth@iup.uni-heidelberg.de)

Received: 9 July 2012 - Published in Clim. Past Discuss.: 23 July 2012

Revised: 16 October 2012 - Accepted: 18 October 2012 - Published: 5 November 2012

\begin{abstract}
Interpreting stable oxygen isotope $\left(\delta^{18} \mathrm{O}\right)$ records from stalagmites is still one of the complex tasks in speleothem research. Here, we present a novel model-based approach, where we force a model describing the processes and modifications of $\delta^{18} \mathrm{O}$ from rain water to speleothem calcite (Oxygen isotope Drip water and Stalagmite Model - ODSM) with the results of a state-of-the-art atmospheric general circulation model enhanced by explicit isotope diagnostics (ECHAM5-wiso). The approach is neither climate nor cave-specific and allows an integrated assessment of the influence of different varying climate variables, e.g. temperature and precipitation amount, on the isotopic composition of drip water and speleothem calcite.

First, we apply and evaluate this new approach under present-day climate conditions using observational data from seven caves from different geographical regions in Europe. Each of these caves provides measured $\delta^{18} \mathrm{O}$ values of drip water and speleothem calcite to which we compare our simulated isotope values. For six of the seven caves modeled $\delta^{18} \mathrm{O}$ values of drip water and speleothem calcite are in good agreement with observed values. The mismatch of the remaining caves might be caused by the complexity of the cave system, beyond the parameterizations included in our cave model.

We then examine the response of the cave system to midHolocene (6000 yr before present, $6 \mathrm{ka}$ ) climate conditions by forcing the ODSM with ECHAM5-wiso results from $6 \mathrm{ka}$ simulations. For a set of twelve European caves, we compare the modeled mid-Holocene-to-modern difference
\end{abstract}

in speleothem calcite $\delta^{18} \mathrm{O}$ to available measurements. We show that the general European changes are simulated well. However, local discrepancies are found, and might be explained either by a too low model resolution, complex local soil-atmosphere interactions affecting evapotranspiration or by cave specific factors such as non-equilibrium fractionation processes.

The mid-Holocene experiment pronounces the potential of the presented approach to analyse $\delta^{18} \mathrm{O}$ variations on a spatially large (regional to global) scale. Modelled as well as measured European $\delta^{18} \mathrm{O}$ values of stalagmite samples suggest the presence of a strong, positive mode of the North Atlantic Oscillation at $6 \mathrm{ka}$ before present, which is supported by the respective modelled climate parameters.

\section{Introduction}

Various studies demonstrate a correlation between oxygen isotopic $\left(\delta^{18} \mathrm{O}\right)$ variations measured in stalagmites and climate changes above the cave (e.g. Van Breukelen et al., 2008; Cheng et al., 2009; Cruz et al., 2005; Fleitmann et al., 2003; Mangini et al., 2005; McDermott et al., 2001; Partin et al., 2007; Wang et al., 2001). However, the $\delta^{18} \mathrm{O}$ signal of speleothem calcite is influenced by atmospheric, soil and cave processes, making the untangling of the climate contributions to the records a challenging task.

Atmospheric variables (e.g. near-surface air temperature and amount of precipitation) and processes (e.g. moisture 
Table 1. Cave locations and compilation of isotope data from monitoring programs. Further information about the caves can be found in the respective references. Drip water $\delta^{18} \mathrm{O}$ values refer to VSMOW and calcite values to VPDB.

\begin{tabular}{|c|c|c|c|c|c|c|c|}
\hline Cave & Latitude & Longitude & Altitude & $\delta^{18} \mathrm{O}_{\text {drip }}$ & $\delta^{18} \mathrm{O}_{\text {calcite }}$ & $\begin{array}{c}\text { Cave monitoring } \\
\text { period }\end{array}$ & Reference \\
\hline $\begin{array}{l}\text { Soylegrotta } \\
\text { (Norway) }\end{array}$ & $66.55^{\circ} \mathrm{N}$ & $13.92^{\circ} \mathrm{E}$ & $100-200 \mathrm{~m}$ & $-10 \pm 0.23 \%$ & $-7.33 \%$ & 1991-1992 & $\begin{array}{l}\text { Lauritzen and } \\
\text { Lundberg (1999) }\end{array}$ \\
\hline $\begin{array}{l}\text { Korallgrottan } \\
\text { (Sweden) }\end{array}$ & $64.89^{\circ} \mathrm{N}$ & $14.16^{\circ} \mathrm{E}$ & $540-600 \mathrm{~m}$ & $-12.02 \pm 0.41 \%$ & $-9.41 \%$ & 2005-2006 & $\begin{array}{l}\text { Sundqvist } \\
\text { et al. (2007) }\end{array}$ \\
\hline $\begin{array}{l}\text { Tartair Cave } \\
\text { (Scotland) }\end{array}$ & $58.14^{\circ} \mathrm{N}$ & $4.93^{\circ} \mathrm{W}$ & $300-500 \mathrm{~m}$ & $-7.09 \pm 0.26 \%$ & $-5.2 \pm 0.35$ & 2003-2005 & $\begin{array}{l}\text { Fuller } \\
\text { et al. (2008) }\end{array}$ \\
\hline $\begin{array}{l}\text { Bunker Cave } \\
\text { (Germany) }\end{array}$ & $51.37^{\circ} \mathrm{N}$ & $7.66^{\circ} \mathrm{E}$ & $184 \mathrm{~m}$ & $-7.91 \pm 0.18 \%$ & $-5.91 \pm 0.30 \%$ & 2006-2011 & $\begin{array}{l}\text { Riechelmann (2010) } \\
\text { Riechelmann } \\
\text { et al. (2011) } \\
\text { Ongoing } \\
\text { monitoring }\end{array}$ \\
\hline $\begin{array}{l}\text { Katerloch } \\
\text { (Austria) }\end{array}$ & $47.25^{\circ} \mathrm{N}$ & $15.55^{\circ} \mathrm{E}$ & $900 \mathrm{~m}$ & $-8.70 \pm 0.10 \%$ & $-6.3 \%$ & 2005-2007 & $\begin{array}{l}\text { Boch et al. } \\
(2009,2010)\end{array}$ \\
\hline $\begin{array}{l}\text { C. G. d. } \\
\text { Giazzera } \\
\text { (Italy) }\end{array}$ & $45.85^{\circ} \mathrm{N}$ & $11.09^{\circ} \mathrm{E}$ & $1025 \mathrm{~m}$ & $-9.18 \pm 0.24 \%$ & $-6.7 \%$ & $\begin{array}{l}2002-2003 \\
2006-2008\end{array}$ & $\begin{array}{l}\text { Frisia } \\
\text { et al. (2007) } \\
\text { Miorandi } \\
\text { et al. (2007) }\end{array}$ \\
\hline $\begin{array}{l}\text { Grotte } \\
\text { de Clamouse } \\
\text { (France) }\end{array}$ & $43.70^{\circ} \mathrm{N}$ & $3.61^{\circ} \mathrm{E}$ & $75 \mathrm{~m}$ & $-6.2 \%$ & $-4.9 \%$ & 1999-2001 & $\begin{array}{l}\text { Frisia } \\
\text { et al. (2002) } \\
\text { Plagnes } \\
\text { et al. (2002) }\end{array}$ \\
\hline
\end{tabular}

source and transport pathway from source to cave) affect the isotopic oxygen composition of meteoric precipitation that results in the drip water in the cave. These effects are described in detail in comprehensive review publications (e.g. Lachniet, 2009; McDermott, 2008; Mook, 2006). The final drip water $\delta^{18} \mathrm{O}$ signal $\left(\delta^{18} \mathrm{O}_{\text {drip }}\right)$ is furthermore influenced by sub-surface processes in the biosphere, pedosphere and karst layer. These processes, such as evapotranspiration, calcite dissolution, the residence time of infiltrating water and mixing of water parcels of different ages, depend on parameters like the temperature, the properties of the soil and karst layer, the $p \mathrm{CO}_{2}$ of soil air and the type and seasonal state of vegetation. The drip water $\delta^{18} \mathrm{O}$ as well as the conditions in the cave affect the final speleothem $\delta^{18} \mathrm{O}$ signal $\left(\delta^{18} \mathrm{O}_{\text {calcite }}\right)$. Cave temperature, the drip interval of the stalactite feeding the stalagmite and supersaturation of the drip water solution with respect to calcite determine the amplitude of the isotopic fractionation between the $\delta^{18} \mathrm{O}$ signal of drip water and speleothem calcite (e.g. Dreybrodt, 2008; Mühlinghaus et al., 2009; O'Neil et al., 1969; Scholz et al., 2009).

For an improved understanding of the relation between climate variables and the $\delta^{18} \mathrm{O}$ signal of speleothems, forward models are used to simulate the processes that modify the $\delta^{18} \mathrm{O}$ signal traveling from the atmosphere through the soil to the cave (Baker and Bradley, 2010; Bradley et al., 2010; Jex et al., 2010; Wackerbarth et al., 2010). In this study we use the Oxygen isotope Drip water and Stalagmite Model, ODSM (Wackerbarth et al., 2010; Wackerbarth, 2012). Instead of forcing the model with observational data (Wackerbarth et al., 2010), here we use the results of a state-of-the-art atmospheric general circulation model with explicit water isotope diagnostics, ECHAM5-wiso (Werner et al., 2011). This approach allows us to simulate the $\delta^{18} \mathrm{O}$ value of drip water and calcite on a global scale and under different climate scenarios. McDermott et al. (2011) highlighted the value of analysing spatially large-scale $\delta^{18} \mathrm{O}_{\text {calcite }}$ variations. They compiled a multitude of Holocene $\delta^{18} \mathrm{O}$ stalagmite samples and observed the changing zonal gradient of these $\delta^{18} \mathrm{O}$ values for different periods throughout the Holocene. By focusing on a compilation of stalagmite samples, the study allows to draw conclusions on the driving reasons for large-scale $\delta^{18} \mathrm{O}$ and climate variation. Our study presents a new approach which aims to contribute to the understanding and analysing of large scale climate variations which is one of the key aspects to understand the driving mechanisms of climate variability.

We first test our approach on seven European caves (Table 1) which all provide both comprehensive present-day climate and monitoring data $\left(\delta^{18} \mathrm{O}_{\text {drip }}\right.$ and recent $\left.\delta^{18} \mathrm{O}_{\text {calcite }}\right)$. The results of an ECHAM5-wiso simulation covering the period 1956-1999 are compared to observed climate variables at the cave locations and used to force the ODSM. The resulting modeled $\delta^{18} \mathrm{O}_{\text {drip }}$ and $\delta^{18} \mathrm{O}_{\text {calcite }}$ are then compared to 
measured values. In the second part of this study, we employ the model approach to the mid-Holocene $(6000 \mathrm{yr}$ before present, $6 \mathrm{ka}$ ), where we compare our modeled $\delta^{18} \mathrm{O}_{\text {calcite }}$ to measured values from twelve European caves.

\section{General model description}

This section gives a short overview of both applied models, the ODSM and the ECHAM5-wiso. Specific experimental setup and simulation results using these models are described in Sect. 3 (present-day experiment) and Sect. 4 (midHolocene experiment).

\subsection{The Oxygen isotope Drip water and Stalagmite Model}

The Oxygen isotope Drip water and Stalagmite Model (ODSM) simulates the modification of the $\delta^{18} \mathrm{O}$ value in precipitation $\left(\delta^{18} \mathrm{O}_{\text {prec }}\right)$ by several processes in the soil and karst matrix (evapotranspiration, calcite dissolution, the residence time of infiltrating water and mixing of water parcels of different ages) to calculate the $\delta^{18} \mathrm{O}$ value of cave drip water $\left(\delta^{18} \mathrm{O}_{\text {drip }}\right)$. Furthermore, calcite precipitation at the stalagmite's surface is considered in order to compute the $\delta^{18} \mathrm{O}$ value of speleothem calcite $\left(\delta^{18} \mathrm{O}_{\text {calcite }}\right)$. The description of isotopic fractionation during calcite precipitation is one of the most challenging tasks in the speleothem science. Mickler et al. (2006) pointed out that for most natural speleothems a pure equilibrium fractionation ("equilibrium" as described in Mook, 2006) cannot be assumed. Since early publications (e.g. Mook, 2006), ongoing research on natural and synthetic calcite precipitates (Friedmann and O'Neil, 1977; Kim and O'Neil, 1997; Coplen, 2007; Tremaine et al, 2011; Feng et al., 2012) stresses the complexity of the topic and how different cave specific parameters (temperature, $p \mathrm{CO}_{2}$ of cave air, calcite precipitation rate, cave ventilation, bicarbonate concentration of the drip water) influence the isotopic fractionation. For estimation of the true extent of isotopic fractionation sophisticated models (e.g. Dreybrodt, 2008; Mühlinghaus et al., 2009; Scholz et al., 2009) must be applied. In principle the ODSM is able to apply kinetic fractionation as described by Mühlinghaus et al. (2009). However, this module require cave specific parameters which are not given for all of the stalagmites in this study. Therefore, we apply the equation by Friedmann and O'Neil (1977) (Eq. 1).

$1000 \times \ln \alpha=\frac{2.78 \times 10^{6}}{T^{2}}-2.89$

The equation leads to 0.3 to $0.8 \%$ o higher values than stated by the frequently used equation by Kim and O'Neil (1997) which is considered to describe the true equilibrium fractionation. However, in a comparison of a compilation of different modern cave $\delta^{18} \mathrm{O}_{\text {drip }}$ and the respective $\delta^{18} \mathrm{O}_{\text {calcite }}$ by McDermott et al. (2005) stated that the Friedmann and O'Neil
(1977) equation yields the most consistent results with measured values. They concluded that Friedmann and O'Neil (1977) seem to be the best representation of the isotopic fractionation during calcite precipitation under natural cave conditions. However, the uncertainty of this topic should be noted and regarded when modelled and stalagmite $\delta^{18} \mathrm{O}$ values are compared.

A more detailed description of ODSM can be found in Wackerbarth (2012).

\subsection{ECHAM5-wiso}

ECHAM5 is the fifth generation of an atmospheric general circulation model developed at the Max-Planck-Institute in Hamburg (Germany). It was thoroughly tested under presentday conditions (e.g. Roeckner et al., 2003, 2006) and used for the last Intergovernmental Panel on Climate Change Assessment Report (Randall et al., 2007). Recently, the ECHAM5 model has been enhanced by a water isotope module in the model's hydrological cycle (ECHAM5-wiso), following the work of Joussaume et al. (1984); Jouzel et al. (1987) and Hoffmann et al. (1998). This enhancement allows an explicit simulation of isotopic changes within the entire hydrological cycle, from ocean evaporation through cloud condensation and precipitation (rain- and snowfall) to surface water reservoirs and runoff. On a global scale (Werner et al., 2011) as well as on a European scale (Langebroek et al., 2011), the ECHAM5-wiso simulation results are in good agreement with available observations of the isotopic composition of precipitation, both on an annual as well as on a seasonal time scale.

\section{Present-day experiment}

In our present-day experiment, we force the ODSM with the results from a present-day simulation using ECHAM5wiso (see Sects. 3.1 and 3.2). Model results are compared to seven well-studied European caves for which climate data and $\delta^{18} \mathrm{O}_{\text {drip }}$ and $\delta^{18} \mathrm{O}_{\text {calcite }}$ are available. We first compare the local ECHAM5-wiso simulation results to observational data above the caves and discuss the differences (Sect. 3.3). We then compare the modeled $\delta^{18} \mathrm{O}_{\text {drip }}$ and $\delta^{18} \mathrm{O}_{\text {calcite }}$ to the measured values within the caves (Sect. 3.4). Finally, we evaluate in a sensitivity study how changes of local surface conditions (temperature, precipitation amount and $\delta^{18} \mathrm{O}_{\text {prec }}$ ) will be imprinted in the simulated $\delta^{18} \mathrm{O}_{\text {drip }}$ and $\delta^{18} \mathrm{O}_{\text {calcite }}$ values (Sect. 3.5), in general.

\subsection{ECHAM5-wiso setup for present-day simulation}

For this study, we are using results of a present-day ECHAM5-wiso simulation covering the period 1956-1999, recently performed by Langebroek et al. (2011). As surface boundary conditions observed monthly mean sea surface temperatures and sea ice cover data (Atmospheric Model 
Intercomparison Project (AMIP)-style forcing, Gates et al., 1999) were used, the $\delta^{18} \mathrm{O}$ values of the ocean surface waters were set to observed modern values, derived from the global gridded data set compiled by LeGrande and Schmidt (2006). The surface waters of large lakes were set to a constant value of $0.5 \%$. The orbital configuration and the concentration of greenhouse gases are set to modern values $\left(\mathrm{CO}_{2}: 348 \mathrm{ppm}\right.$, $\mathrm{CH}_{4}: 1650 \mathrm{ppb}, \mathrm{N}_{2} \mathrm{O}: 306 \mathrm{ppb}$ ).

The ECHAM5-wiso model was forced by sea surface temperatures and sea ice cover only, leaving the atmosphere on inter annual timescales free to evolve. As a consequence the modeled climate of a specific month and year cannot be directly compared to the corresponding monthly mean value in any observational data set. When comparing model results with data, rather long-term mean values and variations shall be applied.

ECHAM5-wiso was ran in a relatively high spectral resolution, T106L31, which corresponds to a horizontal grid resolution of approximately $1.1^{\circ}$ by $1.1^{\circ}$, and 31 layers in the vertical. For more information concerning this simulation and a comparison to observational winter data over Europe, we refer to Langebroek et al. (2011).

\subsection{Forcing the ODSM}

The ODSM is forced by the output values from ECHAM5wiso (temperature, precipitation, evapotranspiration and $\delta^{18} \mathrm{O}_{\text {prec }}$ ) in monthly resolution to capture the seasonality of climate. Due to mixing processes in the soil and karst matrix the $\delta^{18} \mathrm{O}_{\text {prec }}$ signal is smoothed to an infiltration weighted mean $\delta^{18} \mathrm{O}$ value. To estimate the true residence time of water in the epikarst is highly complicated. Boch (2010) denote a residence time of "few years" for Katerloch Cave, Fuller et al. (2008) state 1-10 yr in Tartair Cave and experiments from Bunker Cave using tritium tracer indicate a residence time of $2-3 \mathrm{yr}$ (Kluge et al., 2010). However, we calculated $\delta^{18} \mathrm{O}_{\text {drip }}$ values from monthly infiltration weighted $\delta^{18} \mathrm{O}_{\text {prec }}$ values at Bunker Cave. The variability of the modelled $\delta^{18} \mathrm{O}_{\text {drip }}$ values agrees with the measured variability when the averaging covers 48 months. Therefore, we set in this study the residence time to a default value of 48 months. It should be noted, that the averaging through the epikarst affects only the variance of the $\delta^{18} \mathrm{O}_{\text {drip }}$ values, not the mean values itself.

Another key variable influencing the isotopic signature of the drip water is the amount of evapotranspiration $\left(\mathrm{ET}_{\mathrm{pot}}\right)$ occurring from upper soil layers. $\mathrm{ET}_{\text {pot }}$ strongly depends on local conditions, such as the soil and vegetation types. The complexity of this variable motivated us to select and compare two different methods of computation of $\mathrm{ET}_{\text {pot }}$ : (i) in the first setup (setup 1, named "ECHAM"), we use the monthly mean temperature, $T$, amount of precipitation, $P$, amount of evapotranspiration, $\mathrm{ET}_{\mathrm{pot}}$, and $\delta^{18} \mathrm{O}_{\text {prec }}$ directly as computed by ECHAM5-wiso. (ii) In the second set of experiments (setup 2, "Thornthwaite"), we replace the ECHAM5-wiso $\mathrm{ET}_{\text {pot }}$ values by $\mathrm{ET}_{\text {pot }}$ calculated using the Thornthwaite equation (Thornthwaite and Mather, 1957), where the amount of evapotranspiration depends on the respective monthly temperature and the annual latitudedepending pattern of temperature. Both implementations yield monthly mean $\delta^{18} \mathrm{O}_{\text {drip }}$ and $\delta^{18} \mathrm{O}_{\text {calcite }}$ time series from which long-term mean values and $1-\sigma$ standard deviations are computed. The latter can be compared to the selected observed cave data (Sect. 3.4).

\subsection{Comparison of modeled and measured climate conditions above the caves}

We evaluate our model results at seven European cave sites supplying extensive data from cave monitoring programs. Tables 1 and 2 show the geographic position, mean annual temperature, mean annual amount of meteoric precipitation, precipitation-weighted mean $\delta^{18} \mathrm{O}_{\text {prec }}$, mean $\delta^{18} \mathrm{O}_{\text {drip }}$ and modern $\delta^{18} \mathrm{O}_{\text {calcite }}$ of these caves. For more details on the observational data see the respective references (Table 1).

In general the simulated large-scale temperature, precipitation and $\delta^{18} \mathrm{O}_{\text {prec }}$ patterns are comparable to observations over Europe (Langebroek et al., 2011). However, differences between modeled and measured climate values at specific cave locations occur (Table 2). This can be due to the different lengths of the analysed time periods. With ECHAM5wiso we compute climatological means for a period of $44 \mathrm{yr}$, while the observed data at the respective caves are in most cases from shorter time periods. In addition, the ECHAM5wiso model was run in a spatial resolution of $1.1^{\circ} \times 1.1^{\circ}$. Therefore, it is possible that substantial differences occur between mean climate values of the grid box and the particular cave location. Especially the amount of precipitation and the corresponding $\delta^{18} \mathrm{O}$ values are sensitive to orographic features and the topographic position of the cave in the grid box.

Mean annual temperature: the expected positive temperature gradient from high to mid latitudes is clearly visible in both, the modeled and measured values (Fig. 1a). However, the simulated ECHAM5-wiso temperatures tend to be lower $\left(1.5\right.$ to $3.5^{\circ} \mathrm{C}$ ) than the measured values (except Katerloch Cave and Tartair Cave).

Annual amount of precipitation: the simulated annual amount of precipitation agrees fairly well in all the locations except Tartair Cave and Bunker Cave (Fig. 1b). For Bunker Cave, Clamouse Cave, and Korallgrottan precipitation is too high by 240,160 , and $140 \mathrm{~mm} \mathrm{yr}^{-1}$, respectively, while for Tartair Cave the amount of precipitation is much too low $\left(+1030 \mathrm{~mm} \mathrm{yr}^{-1}\right)$. The discrepancies for Bunker Cave, Clamouse Cave and Korallgrottan agree with the general modelling results for present-day conditions. Langebroek et al. (2011) stated that the amount of winter precipitation (DJF) from ECHAM5-wiso shows slightly higher values than the reanalysis data from ERA40 (Uppala et al., 2005). However, the extremely low precipitation amount modeled by ECHAM5-wiso compared to the observed value at Tartair Cave cannot be explained by this general model deficit, but 
Table 2. Compilation of ECHAM5-wiso results and observational climate data for each cave. The last column shows the difference between modelled and observed data.

\begin{tabular}{|c|c|c|c|c|}
\hline & $\begin{array}{l}\text { Annual mean model results } \\
\pm 1 \sigma \text {-standard deviation }(1956-1999)\end{array}$ & Observational data & Monitoring period & $\begin{array}{r}\text { Simulation offset } \\
\text { (observation }- \text { simulation) }\end{array}$ \\
\hline \multicolumn{5}{|c|}{ Soylegrotta } \\
\hline$P[\mathrm{~mm}]$ & $1120 \pm 180$ & NA & & \\
\hline$T\left[{ }^{\circ} \mathrm{C}\right]$ & $0.2 \pm 0.7$ & 2.7 & 1966-1989 & +2.5 \\
\hline$\delta^{18} \mathrm{O}_{\text {prec }}[\% o]$ & $-10.7 \pm 0.6$ & -9.8 & 1991-1992 & +0.9 \\
\hline $\mathrm{ET}[\mathrm{mm}]$ & $440 \pm 40$ & NA & & \\
\hline$T$ cave $\left[{ }^{\circ} \mathrm{C}\right]$ & & 2.7 & see references Table 1 & +2.5 \\
\hline \multicolumn{5}{|c|}{ Korallgrottan } \\
\hline$P[\mathrm{~mm}]$ & $1000 \pm 110$ & 860 & $1961-1990$ & -140 \\
\hline$T\left[{ }^{\circ} \mathrm{C}\right]$ & $-0.5 \pm 0.8$ & 1 & $1961-1990$ & +1.5 \\
\hline$\delta^{18} \mathrm{O}_{\text {prec }}[\%$ o $]$ & $-12.4 \pm 0.7$ & -13.7 & $1975-1988$ & -1.3 \\
\hline $\mathrm{ET}[\mathrm{mm}]$ & $340 \pm 20$ & NA & & \\
\hline$T$ cave $\left[{ }^{\circ} \mathrm{C}\right]$ & & 2 & see references Table 1 & +2.5 \\
\hline \multicolumn{5}{|c|}{ Tartair } \\
\hline$P[\mathrm{~mm}]$ & $870 \pm 130$ & 1900 & $1971-2000$ & +1030 \\
\hline$T\left[{ }^{\circ} \mathrm{C}\right]$ & $7.7 \pm 0.4$ & 7.1 & $1971-2000$ & -0.6 \\
\hline$\delta^{18} \mathrm{O}_{\text {prec }}[\%$ o $]$ & $-8.1 \pm 0.5$ & -7.1 & $2003-2005$ & +1 \\
\hline $\mathrm{ET}[\mathrm{mm}]$ & $540 \pm 50$ & NA & & \\
\hline$T$ cave $\left[{ }^{\circ} \mathrm{C}\right]$ & & 7.1 & see references Table 1 & -0.6 \\
\hline \multicolumn{5}{|c|}{ Bunker } \\
\hline$P[\mathrm{~mm}]$ & $1140 \pm 140$ & 900 & $1978-2007$ & -240 \\
\hline$T\left[{ }^{\circ} \mathrm{C}\right]$ & $8.4 \pm 0.7$ & 10.5 & $1978-2007$ & +2.1 \\
\hline$\delta^{18} \mathrm{O}_{\text {prec }}[\% o]$ & $-7.7 \pm 0.6$ & -7.7 & 2006-2011 & 0 \\
\hline $\mathrm{ET}[\mathrm{mm}]$ & $600 \pm 30$ & NA & & \\
\hline$T$ cave $\left[{ }^{\circ} \mathrm{C}\right]$ & & 10.8 & see references Table 1 & +2.1 \\
\hline \multicolumn{5}{|c|}{ Katerloch } \\
\hline$P[\mathrm{~mm}]$ & $750 \pm 150$ & 870 & 1973-2004 & +120 \\
\hline$T\left[{ }^{\circ} \mathrm{C}\right]$ & $8.5 \pm 0.7$ & 8 & 2006-2008 & -0.5 \\
\hline$\delta^{18} \mathrm{O}_{\text {prec }}[\% o]$ & $-9.0 \pm 1.0$ & -8.8 & 1973-2004 & +0.2 \\
\hline $\mathrm{ET}[\mathrm{mm}]$ & $540 \pm 50$ & NA & & \\
\hline$T$ cave $\left[{ }^{\circ} \mathrm{C}\right]$ & & 6 & see references Table 1 & -2.5 \\
\hline \multicolumn{5}{|c|}{ Giazzera } \\
\hline$P[\mathrm{~mm}]$ & $910 \pm 160$ & 970 & $1992-2004$ & +60 \\
\hline$T\left[{ }^{\circ} \mathrm{C}\right]$ & $10.9 \pm 0.7$ & 13.3 & 1992-2004 & +2.4 \\
\hline$\delta^{18} \mathrm{O}_{\text {prec }}[\% o]$ & $-7.1 \pm 0.7$ & -8.7 & 2002-2004 & -1.7 \\
\hline $\mathrm{ET}[\mathrm{mm}]$ & $610 \pm 50$ & NA & & \\
\hline$T$ cave $\left[{ }^{\circ} \mathrm{C}\right]$ & & 8.5 & see references Table 1 & -2.4 \\
\hline \multicolumn{5}{|c|}{ Clamouse } \\
\hline$P[\mathrm{~mm}]$ & $760 \pm 120$ & 600 & 2003-2007 & -160 \\
\hline$T\left[{ }^{\circ} \mathrm{C}\right]$ & $11 \pm 0.6$ & 14.5 & 1997-2007 & +3.5 \\
\hline$\delta^{18} \mathrm{O}_{\text {prec }}[\% o]$ & $-6.4 \pm 0.5$ & -5.8 & 1997-2007 & +0.6 \\
\hline $\mathrm{ET}[\mathrm{mm}]$ & $560 \pm 50$ & NA & & \\
\hline$T$ cave $\left[{ }^{\circ} \mathrm{C}\right]$ & & 14.5 & see references Table 1 & +3.5 \\
\hline
\end{tabular}


a)

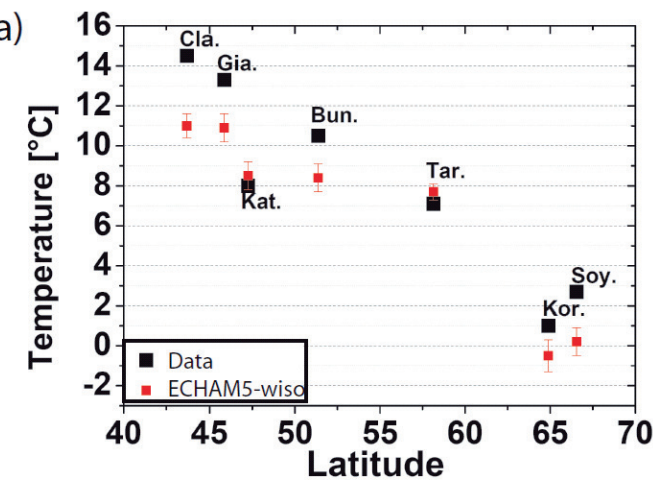

b)

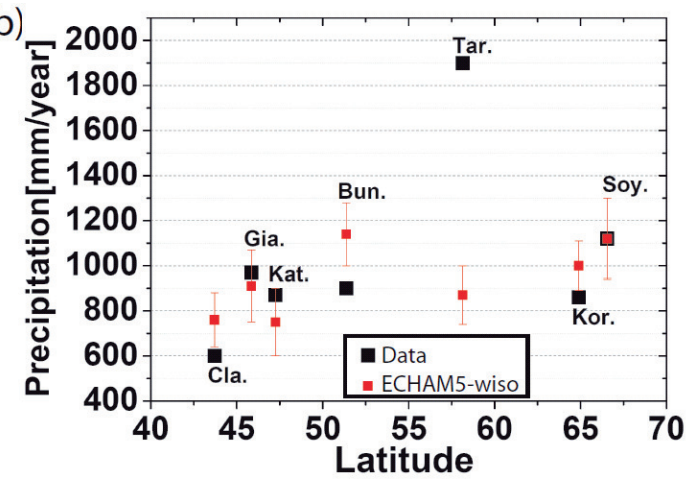

c)

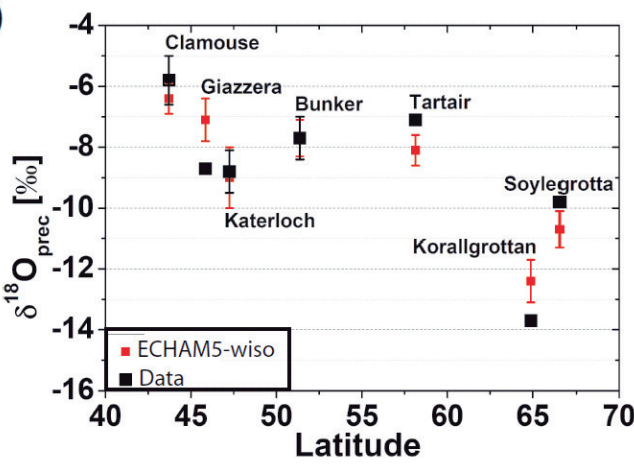

d)

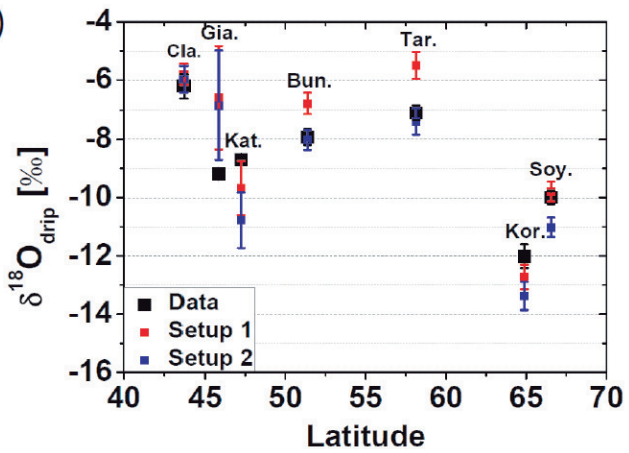

e)

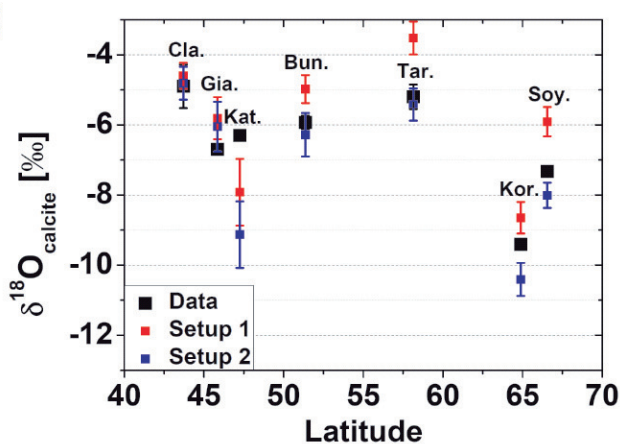

Fig. 1. Comparison of observational data (black) and model results (red: Setup 1 "ECHAM", blue: Setup 2 "Thornthwaite") for each cave for (a) mean annual temperature, (b) annual amount of precipitation, (c) $\delta^{18} \mathrm{O}_{\mathrm{prec}}$, (d) $\delta^{18} \mathrm{O}_{\text {drip }}$, and (e) $\delta^{18} \mathrm{O}_{\text {calcite }}$. Drip water $\delta^{18} \mathrm{O}$ values refer to VSMOW and calcite values to VPDB.

might be caused by the position of the cave. Tartair Cave is located close to the Atlantic Ocean on the weather side of the Scottish Highlands, which could result in much higher precipitation values then the mean value of the respective grid box.

$\delta^{18} \mathrm{O}$ of precipitation: the results of simulated and measured $\delta^{18} \mathrm{O}_{\text {prec }}$ values are displayed in Fig. 1c. In general, the isotopic composition of precipitation depends on (i) the temperature effect, referring directly to lower $\delta^{18} \mathrm{O}_{\text {prec }}$ signal with colder surface temperatures; (ii) the altitude effect describing the isotopic depletion, when an air mass is lifted to higher altitudes due to cooling of the air mass accompanied with a rain-out effect; (iii) the latitude-effect by which an air mass depletes in ${ }^{18} \mathrm{O}$ with increasing latitude due to lower temperatures; and (iv) the continental effect describing the depletion of an air mass through successive rain-out on the path from the coast across landmasses (Mook, 2006). Therefore, the $\delta^{18} \mathrm{O}_{\text {prec }}$ value at a cave location will be lower with decreasing surface temperatures (increasing latitudes), increasing distance from the coast and increasing altitudes, and vice versa.

Observed $\delta^{18} \mathrm{O}_{\text {prec }}$ values: as seen in Fig. 1c, the measured precipitation samples from Soylegrotta and Korallgrottan (high latitude, cold surface temperature) show the lowest $\delta^{18} \mathrm{O}_{\text {prec }}$. The precipitation at Korallgrottan is isotopically lower than at Soylegrotta, since Korallgrottan is located more inland, leading to additional depletion through the rainout effect at Korallgrottan. At Tartair Cave the mean annual 
temperature is about $6^{\circ} \mathrm{C}$ warmer than in Soylegrotta. Therefore, the measured $\delta^{18} \mathrm{O}_{\text {prec }}$ value is heavier by $4 \%$. The observed $\delta^{18} \mathrm{O}_{\text {prec }}$ value for Bunker Cave is similar to Tartair Cave, despite the annual temperature which is about $3.5^{\circ} \mathrm{C}$ warmer at Bunker Cave. However, Bunker Cave is not directly near the shore like Tartair Cave. Thus, the $\delta^{18} \mathrm{O}$ value of precipitation becomes lower on the path from ocean to Bunker Cave counteracting the temperature effect. Though Katerloch Cave lies farther south than Bunker Cave, the location is at a rather high altitude (about $1000 \mathrm{~m}$ ). The $\delta^{18} \mathrm{O}$ values of an an air mass decrease during its way upwards to the cave. Hence, the $\delta^{18} \mathrm{O}_{\text {prec }}$ signal at the cave is lower. In addition the mean annual temperature is colder than at Bunker Cave and the location is farther away from the ocean - two effects that increase the depletion of the $\delta^{18} \mathrm{O}_{\text {prec }}$. Giazzera Cave is located nearly at the same altitude as Katerloch Cave. Surface temperature is about $5{ }^{\circ} \mathrm{C}$ warmer at Giazzera Cave. Therefore, the $\delta^{18} \mathrm{O}_{\text {prec }}$ should be higher than in Katerloch Cave. However, both measured values are nearly the same. The $\delta^{18} \mathrm{O}_{\text {prec }}$ at Clamouse Cave shows the highest observed value. Here the Mediterranean influence might yield higher $\delta^{18} \mathrm{O}_{\text {prec }}$ values, since the Mediterranean Sea is isotopically heavier than the Atlantic Ocean due to high evaporation rates from the relatively small water basin compared to the Atlantic Ocean (Lachniet, 2009).

Simulated $\delta^{18} \mathrm{O}_{\text {prec }}$ values: in general the simulated European $\delta^{18} \mathrm{O}_{\text {prec }}$ values are in fair agreement with the observations. However, some small differences occur at the various cave sites. For Soylegrotta the simulated $\delta^{18} \mathrm{O}_{\text {prec }}$ is too low by $0.9 \%$ which might originate from the simulated annual mean temperature (Table 2), which is $2.5^{\circ} \mathrm{C}$ lower than the observed value. For Korallgrottan the simulated $\delta^{18} \mathrm{O}_{\text {prec }}$ value is $1.3 \%$ o too high when compared to observed data. The reason could be an underestimation of the continental effect depleting the $\delta^{18} \mathrm{O}_{\text {prec }}$ signal of the air mass while transported to the cave. The modeled $\delta^{18} \mathrm{O}_{\text {prec }}$ value at Tartair Cave is again too low (by $1 \%$ ), while for Bunker Cave and Katerloch Cave the modeled values agree well with the data. The $\delta^{18} \mathrm{O}_{\text {prec }}$ at Giazzera Cave is $1.7 \%$ o heavier than the monitoring data, which could possibly be caused by an overestimated influence of the Mediterranean in the model. For Clamouse Cave this influence seems to be present in the model, though the simulated temperatures are $3.5^{\circ} \mathrm{C}$ too low resulting in slightly lower $\delta^{18} \mathrm{O}_{\text {prec }}$ values at the cave's location.

In summary, the comparison between simulated and observed $\delta^{18} \mathrm{O}_{\text {prec }}$ values must be carried out with some caution since the period of observation is in some cases rather short. Only for Bunker Cave, Katerloch Cave and Clamouse Cave could the mean $\delta^{18} \mathrm{O}_{\text {prec }}$ value and standard deviation be given for periods longer than $10 \mathrm{yr}$. For Bunker Cave and Katerloch Cave the standard deviation of the annual weighted $\delta^{18} \mathrm{O}_{\text {prec }}$ is $0.7 \%$. Due to the lack of direct observational data, we assume that the variations are in an equal range also for the other caves. If this assumption is correct, all the modeled and observed values agree within the 2- $\sigma$ standard deviation.

\subsection{Comparison of $\delta^{18} O_{\text {drip }}$ and $\delta^{18} O_{\text {calcite results }}$}

In the following sections and whenever $\delta^{18} \mathrm{O}$ values are stated, calcite $\delta^{18} \mathrm{O}$ values refer to the VPDB standard, while drip water or precipitation $\delta^{18} \mathrm{O}$ values refer to VSMOW.

In the $\delta^{18} \mathrm{O}_{\text {drip }}$ values the characteristic European pattern as discussed for $\delta^{18} \mathrm{O}_{\text {prec }}$ is present in both the simulated and measured values (Fig. 1d). With respect to the simulated amount of evapotranspiration, for four caves setup 1, "ECHAM" seems to be a good representation (Clamouse Cave, Katerloch Cave, Korallgrottan and Soylegrotta). Alternatively, for three caves (Clamouse Cave, Bunker Cave, Tartair Cave) the measured $\delta^{18} \mathrm{O}_{\text {drip }}$ value can be well simulated by the model approach with setup 2 "Thornthwaite". For Giazzera Cave none of the two approaches is in agreement with the measured $\delta^{18} \mathrm{O}_{\text {drip }}$ value.

Assessing the reason for this mismatch is complicated. One reason could be an erroneously modeled seasonal infiltration pattern. Alternatively, the cave system could bear some local features not included in the ODSM.

Overall the general spatial pattern of measured $\delta^{18} \mathrm{O}_{\text {drip }}$ values is well grasped by our model approach. The agreement between modeled and measured $\delta^{18} \mathrm{O}_{\text {drip }}$ values, as calculated by the Root Mean Square Deviation RMSD, is $1.32 \%$ for setup 1 "ECHAM" and $1.36 \%$ for setup 2 "Thornthwaite".

As seen in Fig. $1 \mathrm{~d}$, the simulated $\delta^{18} \mathrm{O}_{\text {drip }}$ and $\delta^{18} \mathrm{O}_{\text {calcite }}$ values from setup 2 ( $\mathrm{ET}_{\mathrm{pot}}$ from Thornthwaite) are significantly lower than from setup 1 (ET $_{\text {pot }}$ from ECHAM5wiso) for nearly all the cave locations. This is caused by lower evapotranspiration rates during winter calculated by the equation from Thornthwaite and Mather (1957) compared to the ECHAM5-wiso computation. Lower winter evapotranspiration leads to higher infiltration rates and to a higher weight of the isotopically lighter winter season. However, in the Mediterranean (Clamouse Cave and Giazzera Cave) both setups agree with each other, indicating that the seasonal patterns of evapotranspiration are similar. These two cases suggest that the model setups yield equivalent results in a warm climate.

In general, three reasons can cause discrepancies between modeled and observed values of $\delta^{18} \mathrm{O}_{\text {drip }}$ : (i) offsets between modeled and observed climate and isotope input parameters and their seasonal pattern lead to shifts in the $\delta^{18} \mathrm{O}_{\text {drip }}$ values (according to the sensitivities discussed in Sect. 3.5). (ii) The modeled seasonal pattern of infiltration might be not representative for the true seasonal pattern. Too high simulated $\delta^{18} \mathrm{O}_{\text {drip }}$ values correspond to an overestimated weight of the warmer season while too low $\delta^{18} \mathrm{O}_{\text {drip }}$ values are assumed to indicate a stronger influence of the colder season. (iii) The enrichment with respect to ${ }^{18} \mathrm{O}$ of the water parcel during evapotranspiration might be overestimated. The percentage 
a)

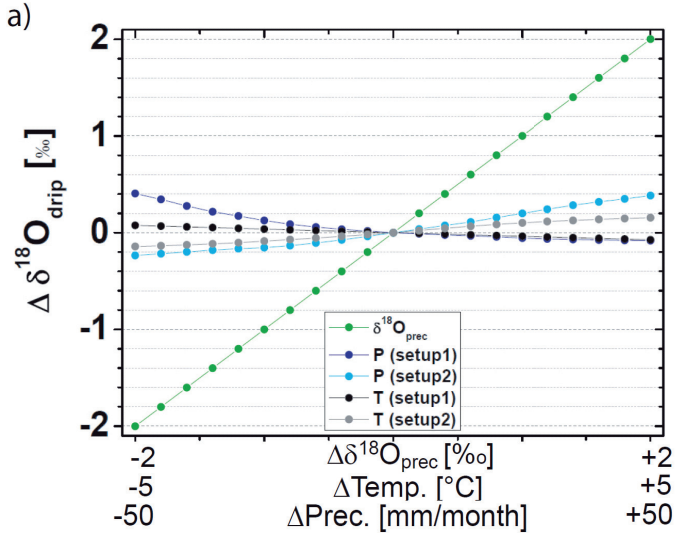

b)

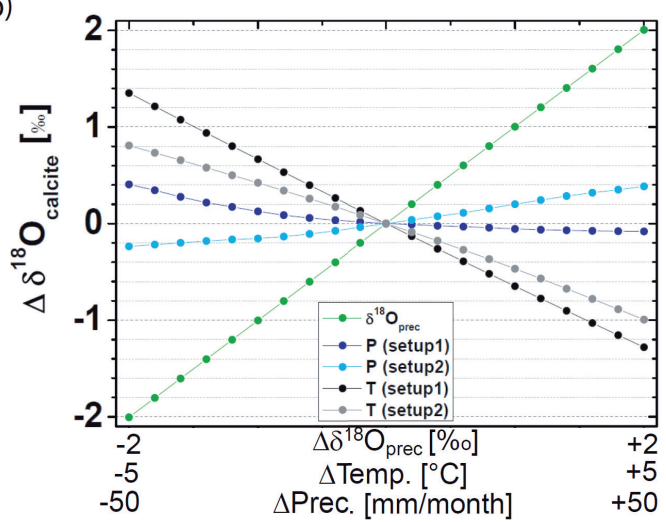

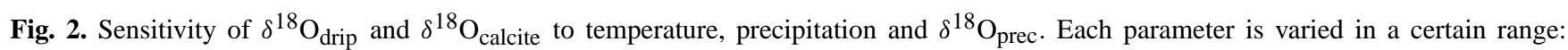
temperature from $-5^{\circ} \mathrm{C}$ to $+5^{\circ} \mathrm{C}$, precipitation from $-50 \mathrm{~mm}$ month ${ }^{-1}$ to $+50 \mathrm{~mm}$ month ${ }^{-1}$ and $\delta^{18} \mathrm{O}_{\text {prec }}$ from -2 to $+2 \%$. The respective parameter shift is added to the whole time series and the ODSM recalculates the (a) mean $\delta^{18} \mathrm{O}_{\text {drip }}$, and (b) mean $\delta^{18} \mathrm{O}_{\text {calcite }}$ with this modified data set. Note, that this figure shows the sensitivity as $\delta^{18} \mathrm{O}$ anomalies with respect to the standard experiment (centre dot). Drip water $\delta^{18} \mathrm{O}$ values refer to VSMOW and calcite values to VPDB.

of evaporation from the amount of evapotranspiration is in the model estimated for the summer season (AMJJAS) to be $20 \%$ and in the winter months (ONDJFM) to be $50 \%$. This could especially be a major problem in warmer regions, since evaporation rates are higher than in colder regions.

The pattern of $\delta^{18} \mathrm{O}_{\text {calcite }}$ is similar to the $\delta^{18} \mathrm{O}_{\text {drip }}$ pattern

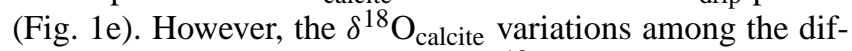
ferent caves are smaller than for $\delta^{18} \mathrm{O}_{\text {drip }}$, because the isotopic fractionation from drip water to calcite is anticorrelated to temperature. This results in relatively smaller differences of the oxygen isotope ratios between drip water and the precipitated calcite in warmer caves and larger differences in colder caves. For the evaluation of modeled $\delta^{18} \mathrm{O}_{\text {drip }}$ and

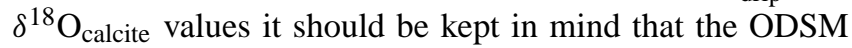
model calculates the isotopic fractionation between drip water and speleothem calcite as occurring under equilibrium conditions. Therefore, the decision if the model approach is representative of the true conditions at the cave should mostly rely on the comparison of $\delta^{18} \mathrm{O}_{\text {drip }}$ values. For example, at Katerloch Cave the simulated $\delta^{18} \mathrm{O}_{\text {drip }}$ agrees with the measured value, while the measured $\delta^{18} \mathrm{O}_{\text {calcite value is }}$ higher than the modeled $\delta^{18} \mathrm{O}_{\text {calcite }}$ value. This is an effect of the kinetic fractionation and additional enrichment of ${ }^{18} \mathrm{O}$ in the calcite during calcite formation, which is not included in the ODSM model due to lack of required input parameters.

\subsection{Sensitivity of $\delta^{18} O_{\text {drip }}$ and $\delta^{18} O_{\text {calcite values }}$ regarding changes of $T, P$ and $\delta^{18} O_{\text {prec }}$}

In principle, a mismatch between modeled and measured

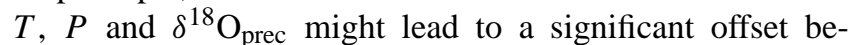
tween the simulated and observed $\delta^{18} \mathrm{O}_{\text {drip }}$ and $\delta^{18} \mathrm{O}_{\text {calcite }}$ values. Therefore, we analyse here the general effect of these variables on the $\delta^{18} \mathrm{O}_{\text {drip }}$ and $\delta^{18} \mathrm{O}_{\text {calcite values. As a }}$ representative, Fig. 2 illustrates the sensitivity of $\delta^{18} \mathrm{O}_{\text {drip }}$ (Fig. 2a) and $\delta^{18} \mathrm{O}_{\text {calcite (Fig. 2b) to changes in } T, P \text { and }}$ $\delta^{18} \mathrm{O}_{\text {prec }}$ for Bunker Cave. Although the sensitivity differs slightly for the other caves, Fig. 2 is a good example to investigate the occurring effects. The x-axes ("sensitivity step") show how temperature, precipitation, $\delta^{18} \mathrm{O}_{\text {prec }}$ are varied in the sensitivity experiment relative to the mean annual values. The investigated temperature range is -5 to $+5^{\circ} \mathrm{C}$, the precipitation range -50 to $+50 \mathrm{~mm} \mathrm{month}^{-1}$ and the $\delta^{18} \mathrm{O}_{\text {prec }}$ is varied from -2 to $+2 \%$.

Temperature sensitivity: the temperature influences the isotopic fractionation during evapotranspiration. There are two counteracting effects: (i) fractionation effect: with decreasing temperature fewer heavy ${ }^{18} \mathrm{O}$ isotopes are evaporated, leading to slightly higher $\delta^{18} \mathrm{O}_{\text {drip }}$ values. According to Majoube (1971) the temperature dependence of the fractionation is small $\left(0.09 \%{ }^{\circ} \mathrm{C}\right)$. (ii) Weighting effect: with increasing temperature, the evapotranspiration increases in the summer months leading to a higher weight of the precipitation from the winter season. This leads to lower $\delta^{18} \mathrm{O}$ values of the drip water, since precipitation from the winter season is isotopically lighter. By adopting the evapotranspiration from ECHAM-wiso (setup 1), we only consider the first temperature effect on $\delta^{18} \mathrm{O}_{\text {drip }}$ (see Fig. 2a, black lines). In contrast, when $\mathrm{ET}_{\text {pot }}$ is computed by the Thornthwaite equation (setup 2), the precipitation weighting effect is also included (Fig. 2a, grey lines). At Bunker Cave this leads to decreasing $\delta^{18} \mathrm{O}_{\text {drip }}$ values with increasing temperature. Compared to the $\delta^{18} \mathrm{O}_{\text {prec }}$ or precipitation sensitivity (see below) the temperature sensitivity of $\delta^{18} \mathrm{O}_{\text {drip }}$ is rather small. The isotopic fractionation with respect to oxygen from drip water to speleothem calcite (Friedmann and O'Neil, 1977) has in general a temperature gradient of about $-0.23 \% /{ }^{\circ} \mathrm{C}$. Hence, the temperature sensitivity of $\delta^{18} \mathrm{O}_{\text {calcite }}$ is affected by this 
gradient on top of the $\delta^{18} \mathrm{O}_{\text {drip }}$ changes (see Fig. 2b, black and grey lines).

Precipitation sensitivity: the influence of a changing amount of precipitation is complex. Two mechanisms must be distinguished: (i) change of the seasonal infiltration pattern. If the monthly mean precipitation amount decreases for all months, the already smaller infiltration in summer due to higher temperatures and more evapotranspiration experiences a larger relative change than the amount of winter infiltration. This shifts the weight to the winter season. As winter $\delta^{18} \mathrm{O}_{\text {prec }}$ shows low values due to low temperatures, the resulting $\delta^{18} \mathrm{O}_{\text {drip }}$ value will be lower as well when the weight of winter precipitation increases. This shift in seasonality affects $\delta^{18} \mathrm{O}_{\text {drip }}$ computed both in setup 1 "ECHAM" and setup 2 "Thornthwaite". (ii) Effect on isotopic fractionation during evapotranspiration (degree of ${ }^{18} \mathrm{O}$ enrichment in the soil water). In setup 2 "Thornthwaite", a decrease in precipitation furthermore may increase the $\delta^{18} \mathrm{O}_{\text {drip }}$ due to the ${ }^{18} \mathrm{O}$ enrichment of the soil water during evapotranspiration caused by diminishing the infiltration/precipitation ratio. In total, both effects (i) and (ii) counteract each other. Therefore, the particular situation at the cave must be considered to estimate which effect prevails.

A major aspect of precipitation is the seasonality, since more or less precipitation yields more or less contribution of this water to the cave drip water. This shifts the $\delta^{18} \mathrm{O}_{\text {drip }}$ value toward the season of the highest infiltration. A shift in seasonality can therefore result in a major variation of the

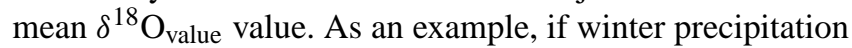
increases the mean $\delta^{18} \mathrm{O}_{\text {drip }}$ decreases to due lower isotopic values during the winter season compared to the summer season. For the $\delta^{18} \mathrm{O}_{\text {calcite, }}$, a shift in seasonality can be even more complicated, since other effects in the cave like supersaturation, cave air $\mathrm{pCO}_{2}$ and ventilation can play a role for the contribution of monthly $\delta^{18} \mathrm{O}_{\text {prec }}$ values to the $\delta^{18} \mathrm{O}_{\text {calcite }}$ value of the growing stalagmite.

$\delta^{18} \mathrm{O}_{\text {prec }}$ sensitivity: a change in the isotopic composition of precipitation does not affect the fractionation occurring in the ODSM. Therefore, a shift of the initial $\delta^{18} \mathrm{O}_{\text {prec }}$ signal can be directly translated into the same shift in $\delta^{18} \mathrm{O}_{\text {drip }}$ and $\delta^{18} \mathrm{O}_{\text {calcite }}$ (Fig. 2, green lines).

\section{Mid-Holocene experiment (6 ka)}

\subsection{Experimental setup of the $6 \mathrm{ka}$ experiment}

After the evaluation of our model setup using present-day climate conditions, we apply our model approach to the climate conditions for $6 \mathrm{ka}$ before present. Unfortunately, only three of the stalagmites from the present-day analysis can be used for comparison with $6 \mathrm{ka}$ (Korallgrottan, Bunker Cave, Clamouse Cave) due to the different growth periods. To extend our analysis, we have therefore selected several other stalagmites which grew in this mid-Holocene period, although these could not be used for the present-day analysis as they do not supply the required cave monitoring data.

We compare the modeled to measured $\delta^{18} \mathrm{O}_{\text {calcite }}$ difference between present-day and $6 \mathrm{ka}$, assuming that local, cave specific model offsets remain constant over this time period. This allows for including caves with offsets in the presentday experiment, like Korallgrottan.

\subsubsection{Studied stalagmites and measured $\Delta \delta^{18} \mathrm{O}_{\text {calcite }}$}

The study from McDermott et al. (2011) gives an excellent overview of European stalagmites, their growth periods and corresponding $\delta^{18} \mathrm{O}_{\text {calcite }}$ values. From this compilation twelve caves were selected (Table 3) with stalagmites that grew at $6 \mathrm{ka}$ as well as at present. For the $6 \mathrm{ka}$ value of the Spannagel Cave, we use the recently updated $\delta^{18} \mathrm{O}_{\text {calcite }}$ value of the COMNISPA record (Vollweiler et al., 2006; Vollweiler, 2010).

Six stalagmites (from Korallgrottan, B7 Cave, Spannagel Cave, Hölloch Cave, Savi Cave, and Garma Cave) reveal higher $\delta^{18} \mathrm{O}_{\text {calcite }}$ value at present-day compared to $6 \mathrm{ka} \mathrm{BP}$, while six others show a lower $\delta^{18} \mathrm{O}_{\text {calcite }}$ values (Poleva Cave, Bunker Cave, Ernesto Cave, Crag Cave, Carburangeli Cave, Clamouse Cave) (Table 3).

\subsubsection{ECHAM-wiso and ODSM setup for the mid-Holocene}

The mid-Holocene ECHAM5-wiso simulations were forced by sea surface temperatures and sea ice cover extracted from transient Holocene simulations performed with three different fully coupled ocean-atmosphere models. By using the forcing derived from three different coupled models, we can compare a range of possible mid-Holocene climate conditions. The three models used are the Community Climate System Model CCSM3 (Collins et al., 2006), COSMOS (Jungclaus et al., 2010) in a coupled atmosphereocean-land surface model version documented in Wei and Lohmann (2012), and ECHO-G (Legutke and Voss, 1999). The transient integrations were performed with identical orbital forcing, pre-industrial level of greenhouse gas concentrations, and were accelerated by a factor of ten. For details on the transient simulations, we refer to Lorenz and Lohmann (2004) for ECHO-G and Varma et al. (2012) for CCSM3 and COSMOS. From these transient simulations, the monthly mean $6 \mathrm{ka}$ and preindustrial values (calculated over a $50-\mathrm{yr}$ period, each) were used to determine $6 \mathrm{ka}$ anomalies of SST and sea ice cover. These anomalies were then added to the present-day AMIP SST and sea ice values and the resulting fields were used as forcing for the ECHAM5-wiso $6 \mathrm{ka}$ time-slice experiments. Thus, our $6 \mathrm{~K}$ simulations are driven by a climatology of monthly mean SST and sea ice cover. This setup is technically different from the ECHAM5-wiso present-day simulation prescribing annually varying monthly mean SST and sea ice fields. However, as we compare in 
Table 3. Cave locations and compilation of isotope data of the studied 12 speleothems with mid-Holocene $(6 \mathrm{ka}) \delta^{18} \mathrm{O}_{\text {calcite }}$ values, extracted from McDermott et al. (2011). Calcite $\delta^{18} \mathrm{O}$ values refer to VPDB.

\begin{tabular}{|c|c|c|c|c|c|c|c|}
\hline Cave & Stal. & Latitude & Longitude & Altitude & $\delta^{18} \mathrm{O}_{\text {calcite }} \mathrm{PD}$ & $\delta^{18} \mathrm{O}_{\text {calcite }} 6 \mathrm{k}$ & Reference \\
\hline $\begin{array}{l}\text { Korallgrottan } \\
\text { (Sweden) }\end{array}$ & K1 & $64.89^{\circ} \mathrm{N}$ & $14.16^{\circ} \mathrm{E}$ & $570 \mathrm{~m}$ & $-8.55 \%$ & $-9.2 \%$ & $\begin{array}{l}\text { Sundqvist et al. } \\
\text { (2007) }\end{array}$ \\
\hline $\begin{array}{l}\text { Crag Cave } \\
\text { (Ireland) }\end{array}$ & $\mathrm{CC} 3$ & $52.23^{\circ} \mathrm{N}$ & $9.44^{\circ} \mathrm{W}$ & $60 \mathrm{~m}$ & $-3.8 \%$ & $-2.9 \%$ & $\begin{array}{l}\text { McDermott et al. } \\
\text { (2001) }\end{array}$ \\
\hline $\begin{array}{l}\text { Bunker Cave } \\
\text { (Germany) }\end{array}$ & BU4 & $51.37^{\circ} \mathrm{N}$ & $7.66^{\circ} \mathrm{E}$ & $184 \mathrm{~m}$ & $-5.7 \%$ & $-5.4 \%$ & $\begin{array}{l}\text { Riechelmann } \\
\text { (2010) }\end{array}$ \\
\hline $\begin{array}{l}\text { B7 Cave } \\
\text { (Germany) }\end{array}$ & B7-5 & $51.34^{\circ} \mathrm{N}$ & $7.65^{\circ} \mathrm{E}$ & $185 \mathrm{~m}$ & $-5.7 \%$ & $-5.8 \%$ & $\begin{array}{l}\text { Niggemann et al. } \\
\text { (2003) }\end{array}$ \\
\hline $\begin{array}{l}\text { Spannagel Cave } \\
\text { (Austria) }\end{array}$ & COMNISPA & $47.09^{\circ} \mathrm{N}$ & $11.67^{\circ} \mathrm{E}$ & $2500 \mathrm{~m}$ & $-7.9 \%$ & $-8.3 \%$ & $\begin{array}{l}\text { Vollweiler } \\
\text { (2010) }\end{array}$ \\
\hline $\begin{array}{l}\text { Hölloch Cave } \\
\text { (Germany) }\end{array}$ & StalHoel1 & $47^{\circ} \mathrm{N}$ & $10^{\circ} \mathrm{E}$ & $1440 \mathrm{~m}$ & $-7.97 \%$ & $-8.27 \%$ & $\begin{array}{l}\text { Wurth et al. } \\
\text { (2004) }\end{array}$ \\
\hline $\begin{array}{l}\text { Ernesto Cave } \\
\text { (Italy) }\end{array}$ & ER76 & $45.96^{\circ} \mathrm{N}$ & $11.65^{\circ} \mathrm{E}$ & $1165 \mathrm{~m}$ & $-7.8 \%$ & $-7.6 \%$ & $\begin{array}{l}\text { See McDermott et al. } \\
\text { (2011) }\end{array}$ \\
\hline $\begin{array}{l}\text { Savi Cave } \\
\text { (Italy) }\end{array}$ & SV1 & $45.61^{\circ} \mathrm{N}$ & $13.88^{\circ} \mathrm{E}$ & $441 \mathrm{~m}$ & $-6.1 \%$ & $-6.74 \% o$ & $\begin{array}{l}\text { Frisia et al. } \\
(2005)\end{array}$ \\
\hline $\begin{array}{l}\text { Poleva Cave } \\
\text { (Romania) }\end{array}$ & PP9 & $44.77^{\circ} \mathrm{N}$ & $21.73^{\circ} \mathrm{E}$ & $390 \mathrm{~m}$ & $-8.62 \%$ & $-7.8 \%$ & $\begin{array}{l}\text { Constantin et al. } \\
\text { (2007) }\end{array}$ \\
\hline $\begin{array}{l}\text { Clamouse Cave } \\
\text { (France) }\end{array}$ & CL26 & $43.7^{\circ} \mathrm{N}$ & $3^{\circ} \mathrm{E}$ & $75 \mathrm{~m}$ & $-4.95 \%$ & $-4.76 \%$ & $\begin{array}{l}\text { McDermott et al. } \\
\text { (1999) }\end{array}$ \\
\hline $\begin{array}{l}\text { Garma Cave } \\
\text { (Spain) }\end{array}$ & Gar01 & $43.43^{\circ} \mathrm{N}$ & $3.66^{\circ} \mathrm{W}$ & $75 \mathrm{~m}$ & $-3.99 \%$ & $-4.39 \%$ & $\begin{array}{l}\text { See McDermott et al. } \\
\text { (2011) }\end{array}$ \\
\hline $\begin{array}{l}\text { Carburangeli } \\
\text { (Italy) }\end{array}$ & CR1 & $38.15^{\circ} \mathrm{N}$ & $13.3^{\circ} \mathrm{E}$ & $22 \mathrm{~m}$ & $-6 \%$ & $-5.5 \%$ & $\begin{array}{l}\text { Frisia et al. } \\
(2006)\end{array}$ \\
\hline
\end{tabular}

the following analyses long-time mean simulation values, only, this difference in the model setup can be neglected. The ECHAM5-wiso simulations were furthermore forced by the $6 \mathrm{ka}$ orbital configuration and greenhouse gas concentrations $\left(\mathrm{CO}_{2}: 280 \mathrm{ppm}, \mathrm{CH}_{4}: 650 \mathrm{ppb}, \mathrm{N}_{2} \mathrm{O}: 270 \mathrm{ppb}\right)$ as agreed upon by the Paleoclimate Modelling Intercomparison Project Phase III (PMIP3, Braconnot et al., 2007).

All three ECHAM5-wiso simulations (with CCSMforcing: ECHAM5-wiso ${ }_{\mathrm{CCSM}}$, COSMOS-forcing: ECHAM5 -wiso COSMOS, and ECHO-G-forcing: ECHAM5-wiso $_{\text {ECHO-G) }}$ ) were run in T106L31 resolution for $12 \mathrm{yr}$. The first two years are regarded as spin-up and the mean of the last $10 \mathrm{yr}$ are used for our data-model comparison. Like for the presentday ECHAM5-wiso simulation, we use the modeled monthly mean values of temperature, precipitation and $\delta^{18} \mathrm{O}_{\text {prec }}$ to compute $\delta^{18} \mathrm{O}_{\text {calcite }}$ using the ODSM. Again we use two setups for estimating the amount of evapotranspiration: (i) taking the evapotranspiration directly as computed by ECHAM5-wiso; and (ii) calculating the evapotranspiration by the Thornthwaite equation using the temperature as computed by ECHAM5-wiso.

\subsection{Comparison of modeled $6 \mathrm{ka}$ temperature, precipitation and $\delta^{18} \mathrm{O}_{\text {prec }}$}

In Fig. 3 the differences between the $6 \mathrm{ka}$ and present-day experiments (6 ka-PD) are given for annual and boreal winter (December-January-February) mean temperature, for precipitation (Fig. 4) and $\delta^{18} \mathrm{O}_{\text {prec }}$ (Fig. 5) over Europe.

The annual mean and boreal winter temperature anomalies reveal significantly lower values in the ECHAM5wiso ${ }_{\text {COSMOS simulation relative to the ECHAM5-wiso }}$ CCSM and ECHAM5-wisoeCHO-G simulations (Fig. 3a-f). In both ECHAM5-wiso ${ }_{\text {ECHO-G and ECHAM5-wiso }}$ CCSM the midHolocene warming is most pronounced in Central Europe.

The mean annual $6 \mathrm{ka}-\mathrm{PD}$ anomaly of precipitation is highest in the ECHAM5-wisocCSM simulation with the most pronounced seasonal cycle (Fig. 4a-f). During winter ECHAM5-wisoCCSM reveals a distinct north-south gradient from wetter to drier conditions with a minimum at Poleva Cave. The same north-south gradient is also visible in ECHAM5-wiso ${ }_{\text {ECHO-G }}$ although less pronounced. ECHAM5-wisocosMos lacks a clear gradient of the precipitation anomaly during winter and reveals hardly any changes 


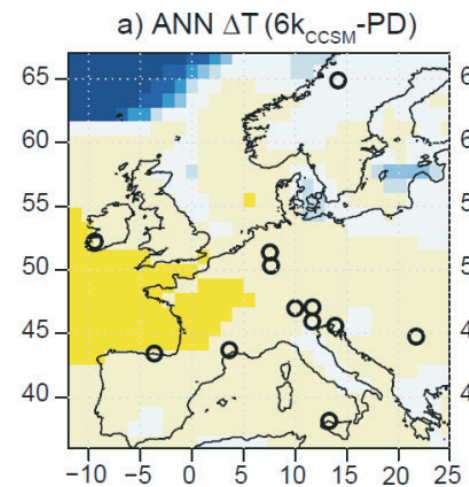

b) ANN $\Delta \mathrm{T}\left(6 \mathrm{k}_{\mathrm{ECHO}-\mathrm{G}^{-}} \mathrm{PD}\right)$

c) ANN $\Delta \mathrm{T}\left(6 \mathrm{k}_{\left.\text {cosmos }^{-P D}\right)}\right.$
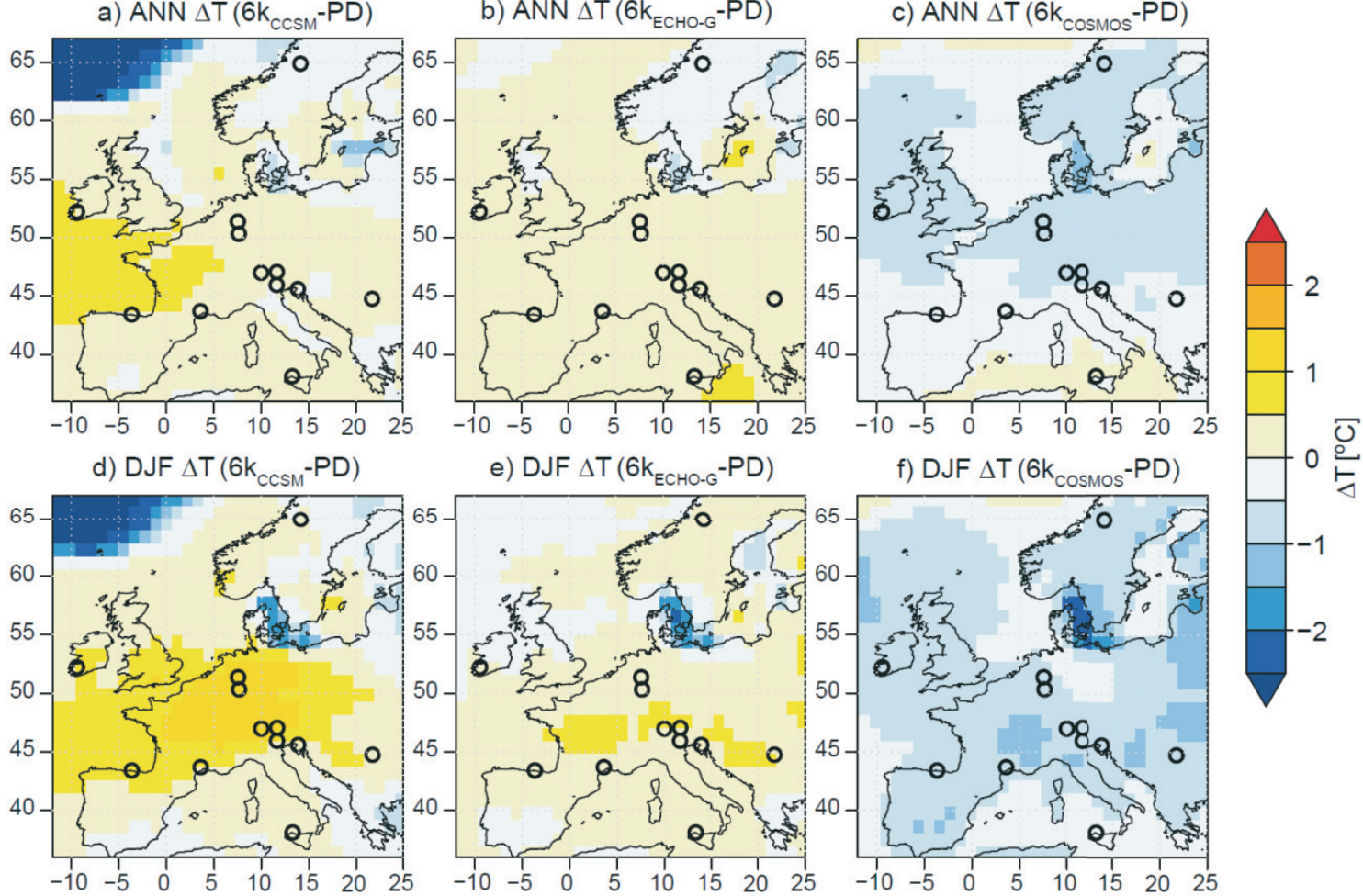

Fig. 3. Temperature anomalies (6k-PD) in Europe as simulated by ECHAM5-wiso forced by sea surface temperatures and sea ice cover extracted from transient Holocene simulations performed with three different fully coupled ocean-atmosphere models (CCSM, COSMOS, ECHO-G). First row: annual mean temperature, second row: winter temperature.
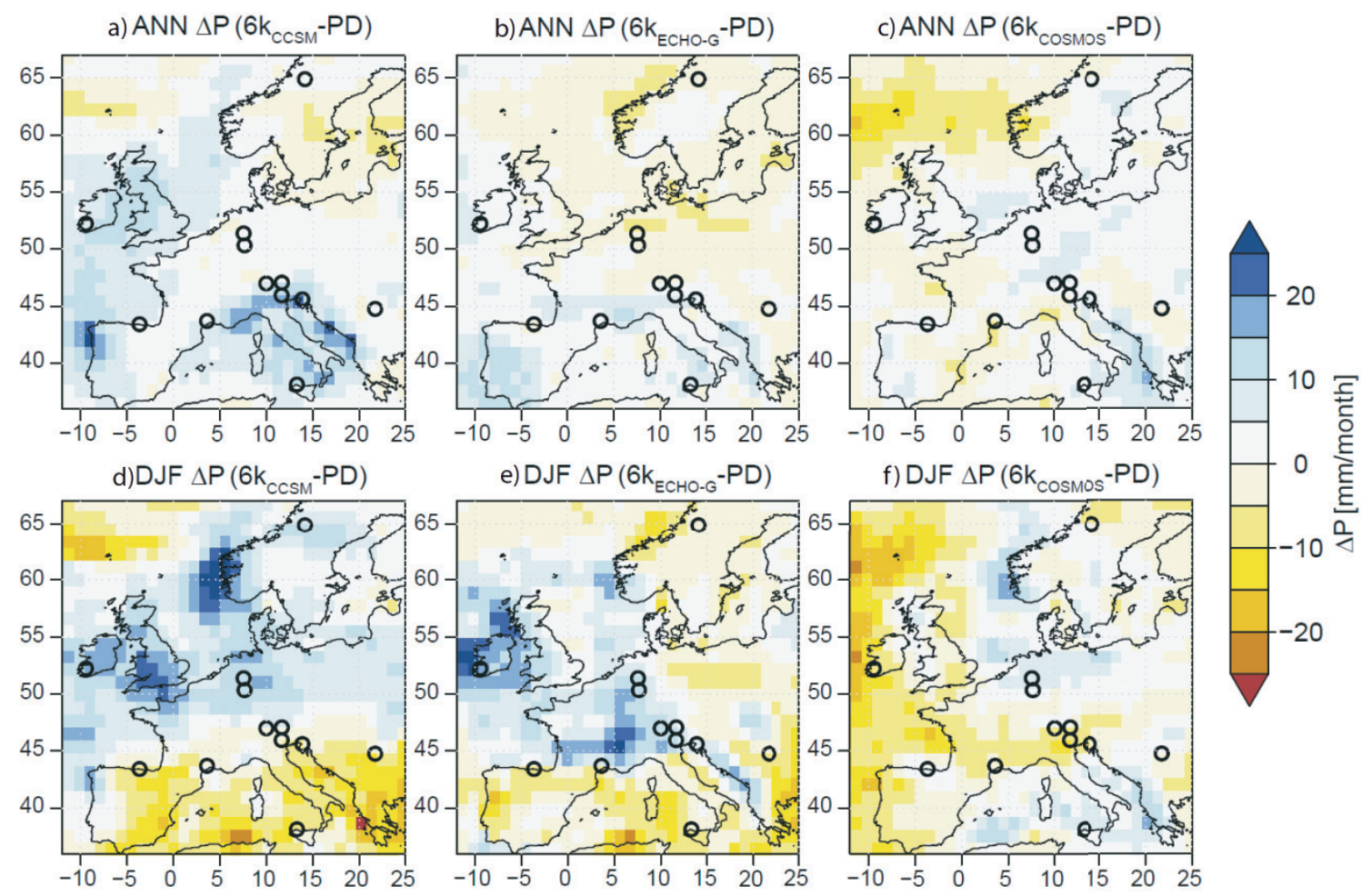

Fig. 4. As Fig. 3, but for precipitation anomalies (6k-PD). 


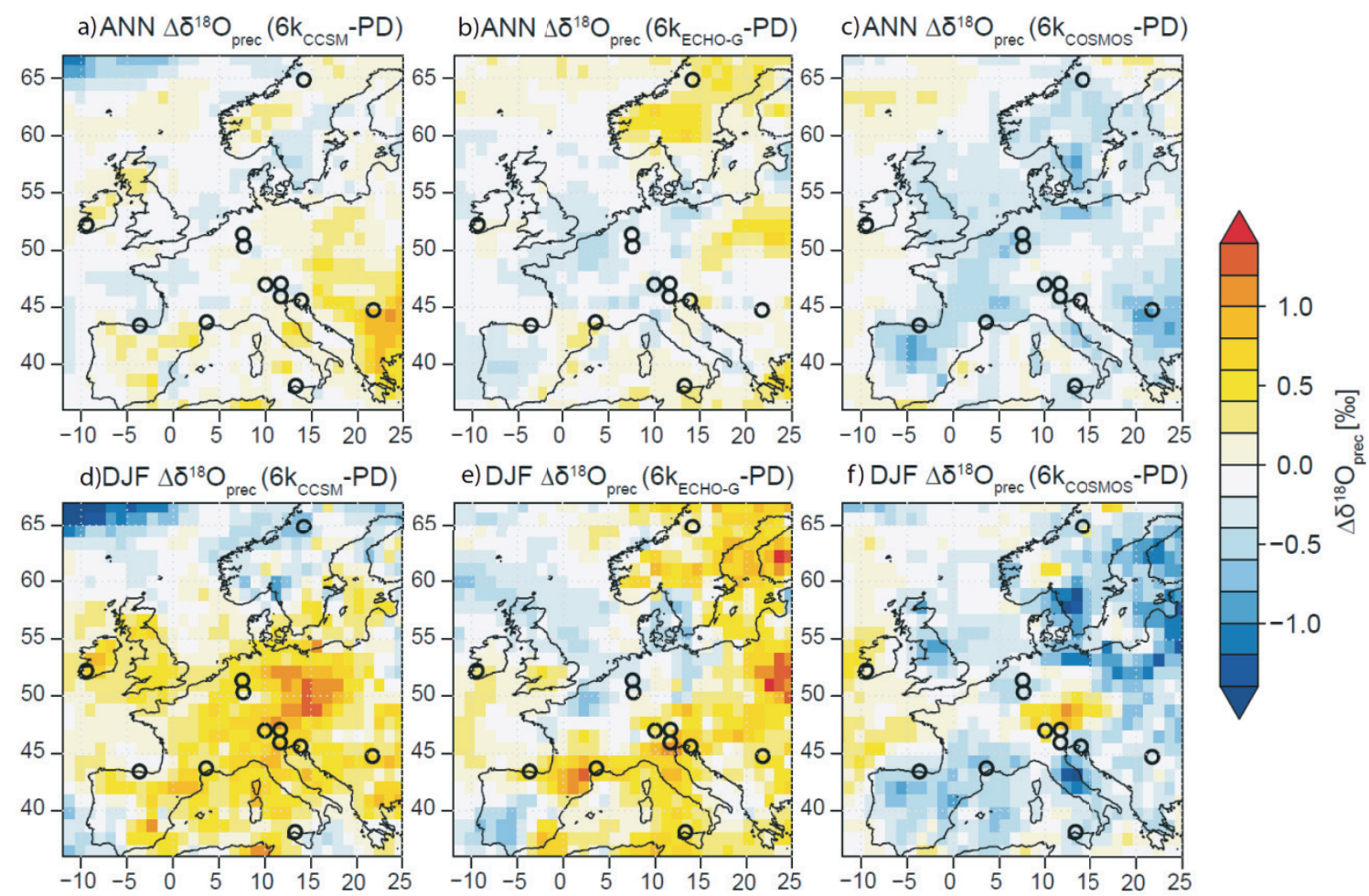

Fig. 5. As Fig. 3, but for $\delta^{18} \mathrm{O}_{\text {prec }}$ anomalies (6k-PD) given relatively to VSMOW standard.

in the annual amount of precipitation from $6 \mathrm{ka}$ to present over the European continent.

The $\delta^{18} \mathrm{O}_{\text {prec }}$ anomalies in the ECHAM5-wisocosmos simulation are most negative (Fig. 5a-f), which can be ascribed to the low temperatures in this experiment. The mean winter $\delta^{18} \mathrm{O}_{\text {prec }}$ anomalies from ECHAM5-wiso ECHO-G reveal a north-west to south-east gradient from negative to positive anomalies, while the spatial pattern from ECHAM5wiso CCSM shows positive anomalies in central Europe and negative in northern and southwestern Europe. In both setups the seasonality is suggested to be more pronounced at 6 ka than today (Fig. 5a, b, d and e).

\subsection{Measured and simulated $\delta^{18} \mathrm{O}_{\text {calcite }}$ anomalies of the mid-Holocene}

The correlation between modeled and measured stalagmite $\Delta \delta^{18} \mathrm{O}_{\text {calcite }}$ (6 ka-PD) anomalies is displayed in Fig. 6, together with calculated RMSD values. The results from ECHAM5-wiso CCSM (both evaporation setups) show the lowest RMSD values and therefore these set ups seem to be the best choice to simulate European $6 \mathrm{ka}$ stalagmite $\Delta \delta^{18} \mathrm{O}_{\text {calcite }}(6 \mathrm{ka}-\mathrm{PD})$ anomalies.

As shown in Fig. 6a and b, the ECHAM5-wiso ${ }_{\text {CCSM re- }}$ sults agree roughly in most $\Delta \delta^{18} \mathrm{O}_{\text {calcite }}(6 \mathrm{ka}-\mathrm{PD})$ anomalies for the Mediterranean stalagmites and up to B7 Cave. For higher latitudes (Crag Cave, Korallgrottan) the modeled values differ from real $\Delta \delta^{18} \mathrm{O}_{\text {calcite }}(6 \mathrm{ka}-\mathrm{PD})$ values. For five caves, the offset between modeled and measured $\Delta \delta^{18} \mathrm{O}_{\text {calcite }}$ (6 ka-PD) values is $0.4 \%$ or greater: Korallgrottan, Crag Cave, Bunker Cave, Savi Cave and Poleva Cave. For Korallgrottan ECHAM5-wiso seems to be unable to simulate the full extend negative isotopic anomalies. The strongly positive anomaly of the $\Delta \delta^{18} \mathrm{O}_{\text {calcite }}$ (6 ka-PD) value in Crag Cave can also not be reached by our model setup. This might be an effect of fractionation kinetics, but without present-day $\delta^{18} \mathrm{O}_{\text {drip }}$ values, the true reason is difficult to determine. In contrast, for Bunker Cave the influence of a strong kinetic was revealed in the present-day experiment. Due to the very low drip rate of the stalagmite from Bunker Cave the influence of fractionation kinetics might have a large effect. For Poleva Cave it is challenging to assess why the cave system is not captured by the model. It is possible that the geographic position in the Carpathians and the influence of the Black Sea versus Mediterranean as source of precipitation complicates the local climate conditions as hinted by Badertscher et al. (2011) for this region.

Figure 7 shows the spatial European pattern of measured and simulated $\Delta \delta^{18} \mathrm{O}_{\text {calcite }}(6 \mathrm{ka}-\mathrm{PD})$ anomalies for the ECHAM5-wiso ${ }_{C C S M}$ simulation. The simulated $\Delta \delta^{18} \mathrm{O}_{\text {calcite }}$ (6 ka-PD) patterns (Fig. $7 \mathrm{~b}$ and c) show less spatial heterogeneity than the measured $\Delta \delta^{18} \mathrm{O}_{\text {calcite }}(6 \mathrm{ka}-\mathrm{PD})$ values (Fig. 7a). The modelling results suggest lowest $\Delta \delta^{18} \mathrm{O}_{\text {calcite }}$ (6 ka-PD) values in central Western Europe and most positive values over southeastern Europe. The difference between 
a)

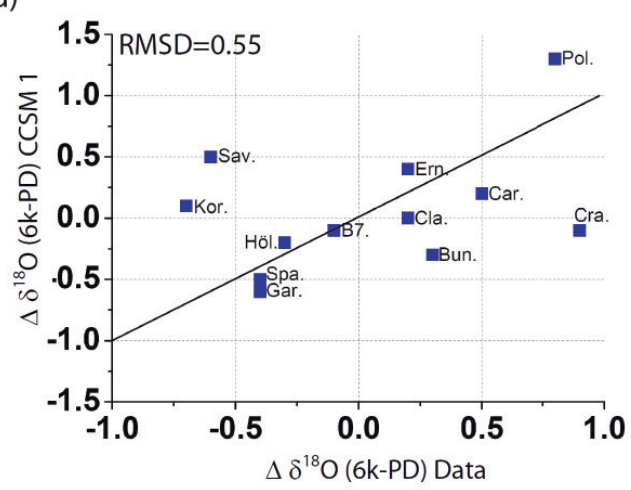

c)

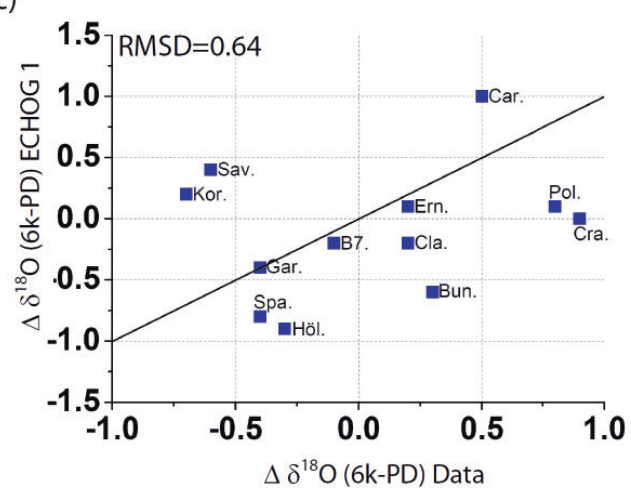

e)

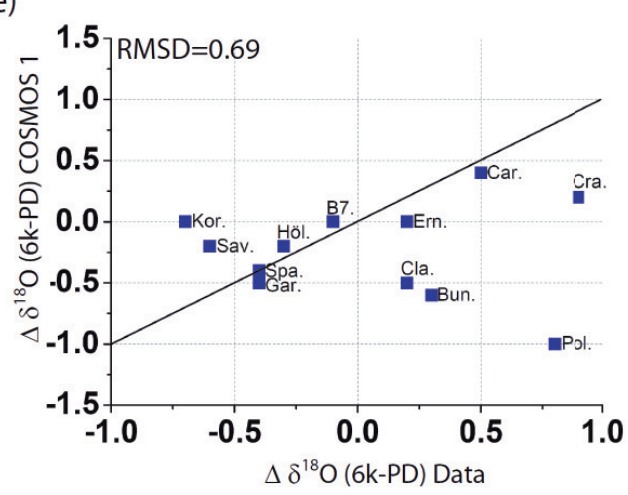

b)

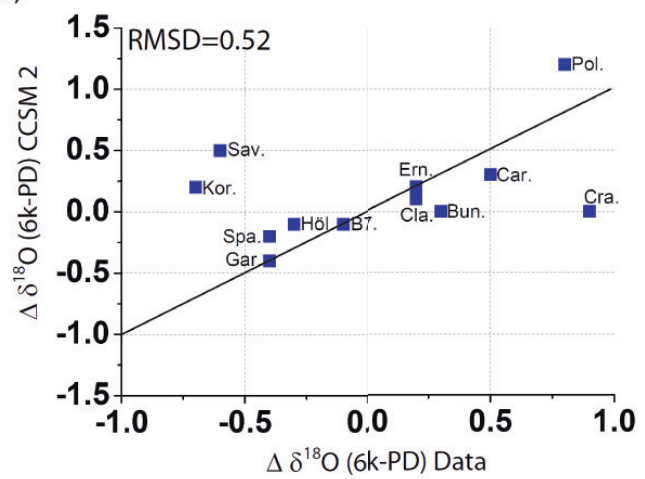

d)

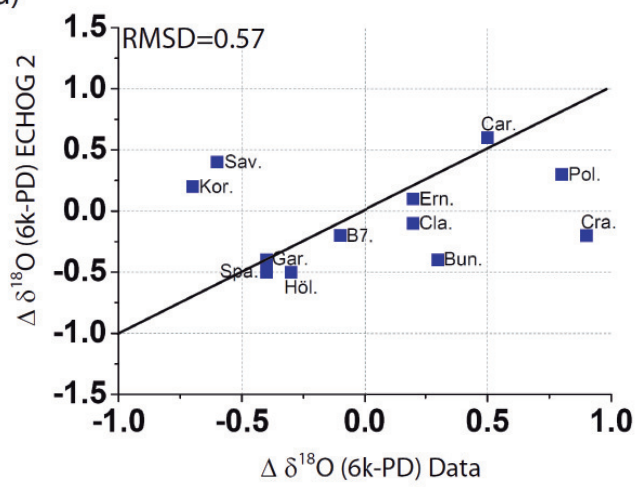

f)

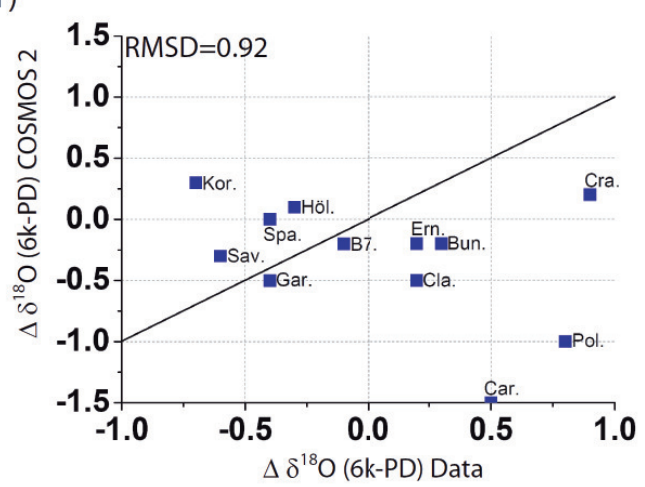

Fig. 6. Modelled versus measured stalagmite $\delta^{18} \mathrm{O}_{\text {calcite }}(6 \mathrm{k}-\mathrm{PD})$ values for the different model setups. The value of the Root Mean Square Deviation, RMSD, gives an evaluation of how well the modelled $\delta^{18} \mathrm{O}_{\text {calcite }}(6 \mathrm{k}-\mathrm{PD})$ values agree with the data. Black lines indicate the $1: 1$ ratio. All calcite $\delta^{18} \mathrm{O}$ values refer to VPDB.

the smooth modeled and the irregular measured $\Delta \delta^{18} \mathrm{O}_{\text {calcite }}$ (6 ka-PD) anomaly patterns indicate that the simulation results lack some location and/or cave specific features.

One major factor influencing the stalagmite $\delta^{18} \mathrm{O}_{\text {calcite }}$ is the kinetic fractionation. With the current model setup this cannot be approximated. Other discrepancies between modeled and measured $6 \mathrm{ka}-\mathrm{PD}$ values might be caused by the $1.1^{\circ} \times 1.1^{\circ}$ resolution of the climate model or by an inadequate representation of the mid-Holocene climate in the simulations. However, by applying a range of different sea surface temperature and sea ice fields (as derived from CCSM3,
ECHO-G and COSMOS), we already capture a broad band of possible mid-Holocene temperature and precipitation patterns in this study.

\subsection{Interpretation of the $6 \mathrm{ka} \delta^{18} \mathrm{O}$ anomalies}

From this study the ECHAM5-wisoCCSM seems to be the best climate model setup to simulate stalagmite data from Europe. The modeled patterns of winter temperature, precipitation and $\delta^{18} \mathrm{O}_{\text {prec }}$ (Figs. 3, 4 and 5) display some 

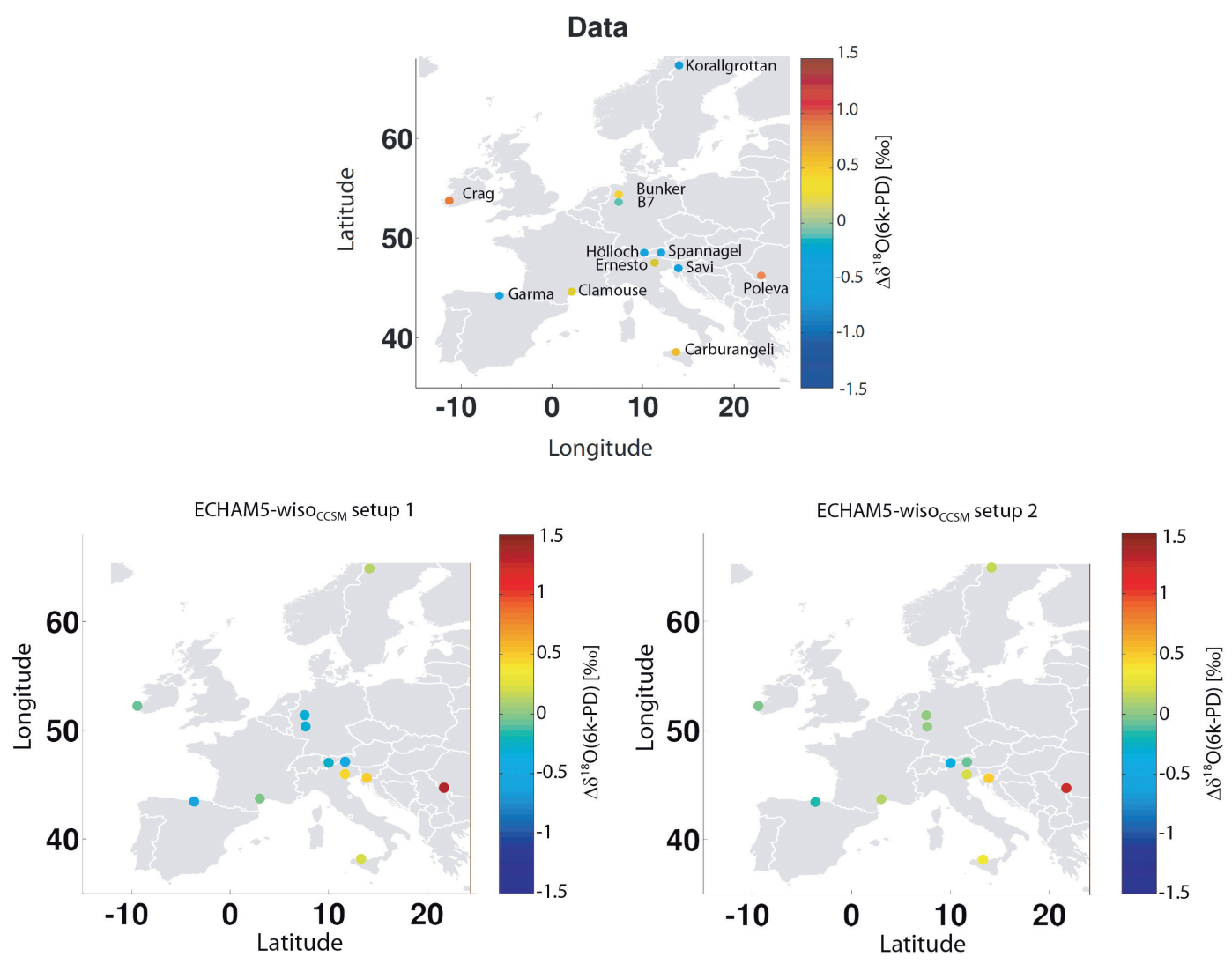

Fig. 7. $\delta^{18} \mathrm{O}_{\text {calcite }}$ difference $6 \mathrm{k}-\mathrm{PD}$ in Europe: (a) measured stalagmite date, (b) and (c) simulated by ECHAM5-wiso coupled with CCSM using two different setups for calculating the amount of evaporation (setup 1 "ECHAM" and setup 2 "Thorntwaite"). The coloured dots represent the cave locations and respective value for $\delta^{18} \mathrm{O}_{\text {calcite }}(6 \mathrm{k}-\mathrm{PD})$ according to the given colour bar.

similarities with a strong positive phase of the North Atlantic Oscillation (NAO).

The basics of the NAO and the impact on the European winter climate conditions are described in several publications (e.g. Hurrel, 2008; Jones et al., 1997; Wanner, 2001). Trigo et al. (2002) and Baldini (2008) determined correlation coefficients between the NAO index and precipitation, temperature and the $\delta^{18} \mathrm{O}_{\text {prec }}$ value for the present-day European winter climate. According to these studies a positive mode of the NAO (NAO+) results in a characteristic $\delta^{18} \mathrm{O}_{\text {calcite }}$ pattern, as shown by Fig. 8 .

During NAO+ strong westerlies from the Atlantic Ocean transport a large amount of precipitation to mid- and northern Europe (accounting for German caves, caves in northern Alps, Garma Cave) during the winter months accompanied by higher winter temperatures and $\delta^{18} \mathrm{O}_{\text {prec }}$ values compared to a negative NAO mode (NAO-). For Crag Cave the correlations of temperature and $\delta^{18} \mathrm{O}_{\text {prec }}$ to NAO are positive, but a correlation to the amount of winter precipitation is not detected (Baldini, 2008). High latitude locations (e.g. Korallgrottan) reveal a negative correlation between $\mathrm{NAO}+$ and $\delta^{18} \mathrm{O}_{\text {prec }}$ and the amount of winter precipitation (Baldini, 2008). In southern Europe (south of the Alps) winter precipitation originates primarily from the Mediterranean during NAO+ and is therefore reduced. During NAOprecipitation has its origin in the Atlantic. Temperature and $\delta^{18} \mathrm{O}_{\text {prec }}$ are positively correlated to the NAO index due to the diminished Atlantic influence (Baldini, 2008). In addition, a strong positive NAO phase is accompanied by a weak Siberian anticyclone restraining cold air from the north to influence the climatic condition in southeast Europe (important for Poleva Cave). The positive correlation to temperature and anticorrelation to precipitation was shown by Winterhalder (2011), Tomozeiu et al. (2002) and Tomozeiu et al. (2005).

The measured $6 \mathrm{ka} \Delta \delta^{18} \mathrm{O}_{\text {calcite }}(6 \mathrm{ka}-\mathrm{PD})$ anomalies resemble the expected NAO+ induced $\Delta \delta^{18} \mathrm{O}_{\text {calcite }}$ (6 ka-PD) pattern to a large extent (Fig. 8). The stalagmites from Korallgrottan, B7 Cave, Spannagel Cave, Hölloch Cave and Garma Cave show lower $6 \mathrm{ka} \delta^{18} \mathrm{O}_{\text {calcite }}$ values compared to present-day, while the samples from Crag Cave, Clamouse Cave, Ernesto Cave, Poleva Cave and Carburangeli Cave reveal positive anomalies. $\delta^{18} \mathrm{O}_{\text {calcite }}$ anomalies. Only two caves (Bunker and Savi Cave) disagree with the expected $\Delta \delta^{18} \mathrm{O}_{\text {calcite }}(6 \mathrm{ka}-\mathrm{PD})$ values. A possible reasons for discrepancies are stalagmite kinetics, offsets between modelled and true seasonal climate parameters, determination 


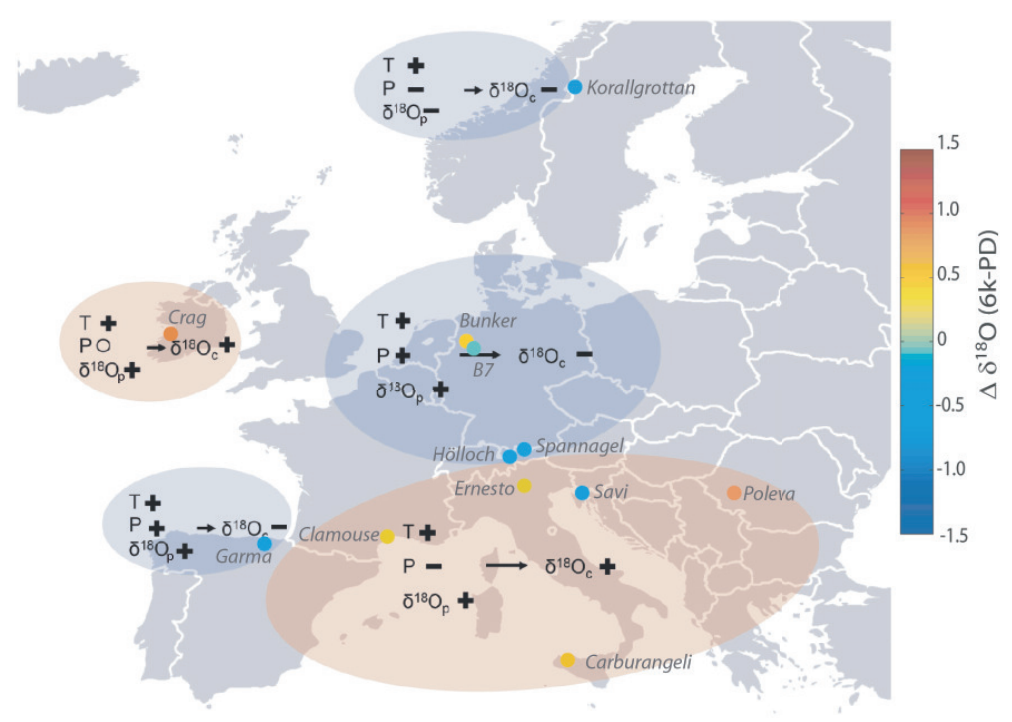

Fig. 8. Scheme illustrating the impact of the positive NAO mode on the European pattern of temperature, precipitation, $\delta^{18} \mathrm{O}_{\text {prec }}$ and the resulting, hypothetical $\delta^{18} \mathrm{O}_{\text {calcite }}$ as discussed in the text. "+" represents an increase, "-" represents a decrease and the circle represents invariance of the respective parameters. Coloured dots represent the measured $6 \mathrm{ka} \delta^{18} \mathrm{O}_{\text {calcite }}$ anomalies from the different speleothems.

of evapotranspiration or the position of the cave in the grid box as discussed above (Sect. 3.4). This characteristic, measured $\Delta \delta^{18} \mathrm{O}_{\text {calcite }}(6 \mathrm{ka}-\mathrm{PD})$ pattern confirms the presence of a positive mode of the NAO at $6 \mathrm{ka}$.

SST-based reconstructions of the NAO (Rimbu et al., 2004), modelling studies of Lorenz and Lohmann (2004), and a collection of proxy evidence summarised by Wanner et al. (2008) also indicate a positive NAO phase during the mid-Holocene. The same statement is supported by Jansen et al. (2007) suggesting an overall temperature increase for Europe compared to pre-industrial times.

In the simulated $\Delta \delta^{18} \mathrm{O}_{\text {calcite }}(6 \mathrm{ka}-\mathrm{PD})$ values from ECHAM5-wisoCCSM, the predicted NAO+ related pattern is also visible, showing a low $\delta^{18} \mathrm{O}_{\text {calcite }}$ values for Garma Cave, Hölloch Cave, Spannagel Cave, Bunker Cave, B7 Cave and higher values in the Mediterranean region (Fig. 7). Outliers are the $\delta^{18} \mathrm{O}_{\text {calcite }}$ values from Korallgrottan and Crag Cave. Although the ECHAM5-wiso output captures the strong NAO+ phase pattern, the other seasons weaken the imprint of the winter season in the drip water and calcite $\delta^{18} \mathrm{O}$ signal.

\section{Summary and conclusions}

We present in this study a new approach that aims to improve our understanding of the climate factors influencing the oxygen isotope ratio measured in stalagmites $\left(\delta^{18} \mathrm{O}_{\text {calcite }}\right)$. We force an Oxygen isotope Drip water and Stalagmite Model (ODSM) with climate variables (temperature, precipitation amount and evapotranspiration) and oxygen isotope values in precipitation $\left(\delta^{18} \mathrm{O}_{\text {prec }}\right)$ computed by an isotope-enabled atmospheric general circulation model (ECHAM5-wiso).
Present-day climate and $\delta^{18} \mathrm{O}$ values: we first test our model approach (forcing the ODSM with ECHAM5-wiso output values) by comparing modeled present-day climate variables and oxygen isotope ratios in cave drip water $\left(\delta^{18} \mathrm{O}_{\text {drip }}\right)$ and $\delta^{18} \mathrm{O}_{\text {calcite }}$ to measured values in seven wellmonitored European caves. The modeled European temperature, precipitation and $\delta^{18} \mathrm{O}_{\text {prec }}$ patterns in general capture the observed patterns. Differences occurring at some cave sites are presumably caused by (i) general offsets between the averaged climate variables of the grid box and the respective values at the cave location or (ii) the different time periods used for the ECHAM5-wiso simulation ( $45 \mathrm{yr}$ ) and measurements (varies per cave, but often just a few years). There is a good agreement between modeled and measured $\delta^{18} \mathrm{O}_{\text {drip }}$ and $\delta^{18} \mathrm{O}_{\text {calcite }}$ for six of the seven investigated European caves (Soylegrotta, Korallgrottan, Tartair Cave, Bunker Cave, Katerloch Cave and Clamouse Cave). Consequently, the observed spatial European pattern of the $\delta^{18} \mathrm{O}_{\text {calcite }}$ values is very well represented by the modeled $\delta^{18} \mathrm{O}_{\text {calcite }}$. Analyzing the influence of the evapotranspiration amount as calculated by two different approaches on $\delta^{18} \mathrm{O}_{\text {calcite }}$ yields a mixed result: for three caves, the evaporation as directly computed by ECHAM5-wiso seems to be the better choice, while for two other caves the evapotranspiration amount as calculated by the Thornthwaite equation fits better to the observations. For two caves, both setups give almost identical results. A general preference of one of the setups can therefore not be derived suggesting the application of both setups for future research projects. Some discrepancies between modeled and measured $\delta^{18} \mathrm{O}_{\text {drip }}$ and $\delta^{18} \mathrm{O}_{\text {calcite }}$ values still remain, which can probably occur due to small-scale local effects, the important, but difficult to compute, evapotranspiration, and in 
case of $\delta^{18} \mathrm{O}_{\text {calcite }}$ values by kinetic fractionation between drip water and speleothem calcite.

Mid-Holocene ( $6 \mathrm{ka}$ ) changes: in the second part of this study we compare ECHAM5-wiso and ODSM simulated $\delta^{18} \mathrm{O}_{\text {calcite }}$ changes between the mid-Holocene $(6 \mathrm{ka})$ and present-day to measured $\delta^{18} \mathrm{O}_{\text {calcite }}$ values for twelve European caves. For this comparison, ECHAM5-wiso was driven by mid-Holocene sea surface temperature and sea ice cover extracted from transient Holocene simulations modeled by three different fully coupled ocean-atmosphere general circulation models (CCSM, COSMOS, ECHO-G). The best representation of the climate condition at $6 \mathrm{ka}$ before present seems to be supplied by the ECHAM5-wiso CCSM simulation. The $T, P$, and $\delta^{18} \mathrm{O}_{\text {prec }}$ values modeled in this setup yield $\Delta \delta^{18} \mathrm{O}_{\text {calcite }}(6 \mathrm{ka}-\mathrm{PD})$ values which resemble the observed values of the European stalagmites. This indicates that the boundary conditions of this setup represent more closely the true European climate during the mid-Holocene. An interesting result of the mid-Holocene experiment is the apparent spatial $\delta^{18} \mathrm{O}_{\text {calcite }}$ pattern across Europe. The measured as well as modelled patterns suggest the presence of a pronounced positive mode of the North Atlantic Oscillation. The terrestrial climate pattern which is related to a NAO+ mode can be observed in the ECHAM5-wiso ${ }_{\text {CCSM }}$ simulated climate parameters at $6 \mathrm{ka} \mathrm{BP}$.

This study demonstrates that our approach to simulate $\delta^{18} \mathrm{O}_{\text {calcite }}$ values by using the ECHAM5-wiso atmosphere general circulation model with explicit water isotope diagnostics as input for the ODSM is a helpful tool to understand $\delta^{18} \mathrm{O}_{\text {calcite }}$ changes of the past and will be a valuable tool to investigate other past time slices as well. In the future we intend to simulate more Holocene time slices in combination with as much stalagmite data as possible for an improved evaluation of the presented model results. This will allow us to assess whether the detected discrepancies at specific cave sites between $6 \mathrm{ka}$ model and stalagmite $\delta^{18} \mathrm{O}_{\text {calcite }}$ data are a temporally varying problem (stalagmite kinetics) or a systematic offset (for example, caused by the geographical position of the cave).

Acknowledgements. This work is funded by DFG grant 668 (DAPHNE).

Edited by: C. Spötl

\section{References}

Baker, A. and Bradley, C.: Modern stalagmite $\delta^{18} \mathrm{O}$ : Instrumental calibration and forward modelling, Global Planet. Change, 71, 201-206, 2010.

Badertscher, S., Fleitmann, D., Cheng, H., Edwards, R. L., Göktürk, O. M., Zumbühl, A., Leuenberger, M., and Tüysüz, O.: Pleistocene water intrusions from the Mediterranean and Caspian seas into the Black Sea, Nat. Geosci., 4, 236-239, 2011.
Baldini, L. M., McDermott, F., Foley, A. M., and Baldini, J. U. L.: Spatial variability in the European winter precipitation $\delta^{18} \mathrm{O}-$ NAO relationship: Implications for reconstructing NAO mode climate variability in the Holocene, Geophys. Res. Lett., 35, L04709, doi:10.1029/2007GL032027, 2008.

Boch, R., Spötl, C., and Kramers, J.: High-resolution isotope records of early Holocene rapid climate change from two coeval stalagmites of Katerloch Cave, Austria, Quaternary Sci. Rev., 28, 2527-2538, 2009.

Boch, R., Spötl, C., and Frisia, S.: Origin and palaeoenvironmental significance of lamination in stalagmites from Katerloch Cave, Austria, Sedimentology, 58, 508-531, 2010.

Braconnot, P., Otto-Bliesner, B., Harrison, S., Joussaume, S., Peterchmitt, J.-Y., Abe-Ouchi, A., Crucifix, M., Driesschaert, E., Fichefet, Th., Hewitt, C. D., Kageyama, M., Kitoh, A., Laîné, A., Loutre, M.-F., Marti, O., Merkel, U., Ramstein, G., Valdes, P., Weber, S. L., Yu, Y., and Zhao, Y.: Results of PMIP2 coupled simulations of the Mid-Holocene and Last Glacial Maximum Part 1: experiments and large-scale features, Clim. Past, 3, 261277, doi:10.5194/cp-3-261-2007, 2007.

Bradley, C., Baker, A., Jex, C. N., and Leng, M. J.: Hydrological uncertainties in the modelling of cave drip-water $\delta^{18} \mathrm{O}$ and the implications for stalagmite palaeoclimate reconstructions, Quaternary Sci. Rev., 29, 2201-2214, 2010.

Cheng, H., Edwards, L. R., Broecker, W. S., Denton, G. H., Kong, X., Wang, Y., Zhang, R., and Wang, X.: Ice Age Terminations, Science, 326, 248-252, 2009.

Collins, W. D., Bitz, C. M., Blackmon, M. L., Bonan, G. B., Bretherton, C. S., Carton, J. A., Chang, P., Doney, S. C., Hack, J. J., Henderson, T. B., Kiehl, J. T., Large, W. G., McKenna, D. S., Santer, B. D., and Smith, R. D.: The Community Climate System Model Version 3 (CCSM3), J. Climate, 19, 2122-2143, 2006.

Constantin, S., Bojar, A. V., Lauritzen, S. E., and Lundberg, J.: Holocene and Late Pleistocene climate in the sub-Mediterranean continental environment: A speleothem record from Poleva Cave (Southern Carpathians, Romania), Palaeogeogr. Palaeocl., 243, 322-338, 2007.

Coplen, T. B.: Calibration of the calcite-water oxygen-isotope geothermometer at Devils Hole, Nevada, a natural laboratory, Geochim. Cosmochim. Acta, 71, 3948-3957, 2007.

Cruz, F. W., Burns, S. J., Karmann, I., Sharp, W. D., Vuille, M., Cardoso, A. O., Ferrari, J. A., Silva Dias, P. L., and Viania, O.: Insolation-driven changes in atmospheric circulation over the past 116,000 years in subtropical Brazil, Nature, 434, 63-66, 2005.

Dreybrodt, W.: Evolution of the isotopic composition of carbon and oxygen in a calcite precipitating $\mathrm{H}_{2} \mathrm{O}-\mathrm{CO}_{2}-\mathrm{CaCO}_{3}$ solution and the related isotopic composition of calcite in stalagmites, Geochim. Cosmochim. Acta, 72, 4712-4724, 2008.

Feng, W., Banner, J. L., Guilfoyle, A. L., Musgrove, M. L., and James, E.: Oxygen isotopic fractionation between drip water and speleothem calcite: A 10-year monitoring study, central Texas, USA, Chem. Geol., 304-305, 53-67, 2012.

Fleitmann, D., Burns, S. J., and Mudelsee, M.: Holocene forcing of the Indian monsoon recorded in a stalagmite from Southern Oman, Science, 300, 1737-1739, 2003. 
Friedmann, I. and O'Neil, J. R.: Compilation of stable isotope fractionation factors of geochemical interest in: Data of Geochemistry 6th Edn., 1, 12, edited by: Fleischer, M., US Geol. Survey Prof. Paper 440 KK, US Geol. Survey, Washington, 1977.

Frisia, S., Borsato, A., Fairchild, I. J., McDermott, F., and Selmo, E. M.: Aragonite-Calcite Relationships in Speleothems (Grotte de Clamouse, France) Environment, Fabrics and Carbonate Geochemistry, J. Sediment. Res., 72, 687-699, 2002.

Frisia, S., Borsato, A., Spötl, C., Miorandi, R., Villa, I., and Cucchi, F.: Climate variability in the South-Eastern Alps of Italy over the last 17.000 years reconstructed from stalagmite records, Boreas, 34, 445-455, 2005.

Frisia, S., Borsato, A., Mangini, A., Spötl, C., Madonia, G., and Sauro, U.: Holocene record of climate changes and land use in Sicily reconstructed from a stalagmite, Quatern. Res., 66, 388400, 2006.

Frisia, S., Borsato, A., Richards, D. A., Miorandi, R., and Davanzo, S.: Variazioni climatiche ed eventi sismici negli ultimi 4500 anni nel Trentino Meridionale da una stalagmite della Cogola Grande di Giazzera implicazioni per gli studi climatico-ambientali da speleotemi, Studi Trentini di Scienze Naturali, Acta Geol., 82, 205-223, 2007.

Fuller, L., Baker, A., Fairchild, I. J., Spötl, C., Marca-Bell, A., Rowe, P., and Dennis, P. F.: Isotope hydrology of dripwaters in a Scottish cave and implications for stalagmite palaeoclimate research, Hydrol. Earth Syst. Sci., 12, 1065-1074, doi:10.5194/hess-12-1065-2008, 2008.

Gates, W. L., Boyle, J. S., Covey, G. C., Dease, C. G., Doutriaux, C. M., Drach, R. S., Fiorino, M., Gleckler, P. J., Hnilo, J. J., Marlais, S. M., Phillips, T. J., Potter, G. L., Santer, B. D., Sperber, K. R., Taylor, K. E., and Williams, D. N.: An overview of the results of the Atmospheric Model Intercomparison Project (AMIP I), B. Am. Meteorol. Soc., 80, 29-55, 1999.

Hoffmann, G., Werner, M., and Heimann, M.: Water isotope module of the ECHAM atmospheric general circulation model - A study on timescales from days to several years, J. Geophys. Res., 103, 16871-16896, 1998.

Hurrell, J. W.: Decadal Trends in the North Atlantic Oscillation: Regional Temperatures and Preciptiation, Science, 269, 676-679, 1995.

Jansen, E., Overpeck, J., Briffa, K. R., Duplessy, J.-C., Joos, F., Masson-Delmotte, V., Olago, D., Otto-Bliesner, B., Peltier, W. R., Rahmstorf, S., Ramesh, R., Raynaud, D., Rind, D., Solomina, O., Villalba, R., and Zhang, D.: Climate Change 2007: The Physical Science Basis. Contribution of Working Group I to the Fourth Assessment Report of the Intergovernmental Panel on Climate Change, in: Palaeoclimate, Cambridge University Press, Cambridge, UK and New York, NY, USA, 434-498, 2007.

Jex, C., Baker, A., Fairchild, I. J., Eastwood, W. J., Leng, M., Sloane, H. J., Thomas, L., and Bekaroglu, E.: Calibration of speleothem $\delta^{18} \mathrm{O}$ with instrumental climate records from Turkey, Global Planet. Change 71, 207-217, 2010.

Jones, P. D., Jonsson, T., and Wheeler, D.: Extension to the North Atlantic Oscillation using early instrumental pressure observations from Gibraltar and south-west Iceland, Int. J. Climatol., 17, 1433-1450, 1997.

Joussaume, S., Sadourny, R., and Jouzel, J.: A general circulation model of water isotope cycles in the atmosphere, Nature, 311, 24-29, 1984.
Jouzel, J., Russell, G. L., Suozzo, R. J., Koster, D., White, J. W. C., and Broecker, W. S.: Simulations of the $\mathrm{HDO}$ and $\mathrm{H}_{18} \mathrm{O}$ atmospheric cycles using the NASA GISS general circulation model: The seasonal cycle for present- day conditions, J. Geophys. Res., 92, 14739-14760, 1987.

Jungclaus, J. H., Lorenz, S. J., Timmreck, C., Reick, C. H., Brovkin, V., Six, K., Segschneider, J., Giorgetta, M. A., Crowley, T. J., Pongratz, J., Krivova, N. A., Vieira, L. E., Solanki, S. K., Klocke, D., Botzet, M., Esch, M., Gayler, V., Haak, H., Raddatz, T. J., Roeckner, E., Schnur, R., Widmann, H., Claussen, M., Stevens, B., and Marotzke, J.: Climate and carbon-cycle variability over the last millennium, Clim. Past, 6, 723-737, doi:10.5194/cp-6723-2010, 2010.

Kim, S.-T. and O'Neil, J. R.: Equilibrium and nonequilibrium oxygen isotope effects in synthetic carbonates, Geochim. Cosmochim. Acta, 61, 3461-3475, 1997.

Kluge, T., Riechelmann, D. F. C., Wieser, M., Spötl, C., Sültenfuss, J., Schröder-Ritzrau, A., Niggemann, S., and Aeschbach-Hertig, W.: Dating cave drip water by tritium, J. Hydrol., 394, 396-406, 2010.

Lachniet, M. S.: Climatic and environmental controls on speleothem oxygen-isotope values, Quaternary Sci. Rev., 28, 412-432, 2009.

Langebroek, P. M., Werner, M., and Lohmann, G.: Climate information imprinted in oxygen-isotopic composition of precipitation in Europe, Earth Planet. Sc. Lett., 311, 144-154, doi:10.1016/j.epsl.2011.08.049, 2011.

Lauritzen, S.-E. and Lundberg, J.: Calibration of the speleothem delta function: an absolute temperature record fort he Holocene in northern Norway, Holocene, 9, 659-669, 1999.

LeGrande, A. N. and Schmidt, G. A.: Global gridded data set of the oxygen isotopic composition in seawater, Geophys. Res. Lett. 33, L12604, doi:10.1029/2006GL026011, 2006.

Legutke, S. and Voss, R.: The Hamburg atmosphere-ocean coupled circulation model ECHO-G/DKRZ, Forschungsbericht, Hamburg, Germany, 1999.

Lorenz, S. and Lohmann, G.: Acceleration technique for Milankovitch type forcing in a coupled atmosphere-ocean circulation model: method and application for the Holocene, Clim. Dynam., 23, 727-743, 2004.

Majoube, M.: Fractionnement en oxygen-18 et en deuterium entre l'eau et sa vapeur, Journal de Chimie Physique, 68, 1423-1436, 1971.

Mangini, A., Spötl, C., and Verdes, P.: Reconstruction of temperature in the Central Alps during the past $2000 \mathrm{yr}$ from a $\delta^{18} \mathrm{O}$ stalagmite record, Earth Planet. Sc. Lett., 235, 741-751, 2005.

McDermott, F.: Palaeo-climate reconstruction from stable isotope variations in speleothems: a review, Quaternary Sci. Rev., 23 , 901-918, 2004.

McDermott, F., Frisia, S., Huang, Y. M., Longinelli, A., Spiro, B., Heaton, T. H. E., Hawkesworth, C. J., Borsato, A., Keppens, E., Fairchild, I. J., van der Borg, K., Verheyden, S., and Selmo, E.: Holocene climate variability in Europe: Evidence from $\delta^{18} \mathrm{O}$, textural and extension-rate variations in three speleothems, Quaternary Sci. Rev., 8-9, 1021-1038, 1999.

McDermott, F., Mattey, D. P., and Hawkesworth, C.: CentennialScale Holocene Climate Variability Revealed by a HighResolution Speleothem $\delta^{18}$ O Record from SW Ireland, Science, 294, 1326-1331, 2001. 
McDermott, F., Schwarcz, H., and Rowe, P. J.: Isotopes in Speleothems, in: Isotopes in Palaeoenvironmental Research, edited by: Leng, M. J., Springer, 185-226, 2005.

McDermott, F., Atkinson, T. C., Fairchild, I. J., Baldini, L. M., and Mattey, D. P.: A first evaluation of the spatial gradients in $\mathrm{d} 18 \mathrm{O}$ recorded by European Holocene speleothems, Global Planet. Change, 79, 275-287, 2011.

Mickler, P. J., Stern, L. A., and Banner, J. L.: Large kinetic isotope effects in modern speleothems, GSA Bulletin 118 (no. 1/2), 6581, 2006.

Miorandi, R., Borsato, A., Frisia, S., and Zandonati, M.: Monitoraggio di aria e acqua di percolazione in alcune grotte del Trentino, Studi Trentini di Scienze Naturali, Acta Geol., 82, 151-164, 2007.

Mook, W. G.: Introduction to Isotope Hydrology, Taylor \& Francis Group, 2006.

Mühlinghaus, C., Scholz, D., and Mangini, A.: Modelling fractionation of stable isotopes in stalagmites, Geochim. Cosmochim. Acta, 73, 7275-7289, 2009.

Niggemann, S., Mangini, A., Mudelsee, M., Richter, D. K., and Wurth, G.: Sub Milankovitch climatic cycles in Holocene stalagmites from Sauerland, Germany, Earth Planet Sc. Lett., 216, 539-547, 2003.

O’Neil, J. R., Clayton, R. N., and Mayeda, T. K.: Oxygen Isotope Fractionation in Divalent Metal Carbonates, J. Chem. Phys., 51, 5547-5558, 1969.

Partin, J. W., Cobb, K. M., Adkins, J. F., Clark, B., and Fernandez, D. P.: Millennial-scale trends in west Pacific warm pool hydrology since the Last Glacial Maximum, Nature, 449, 452-455, 2007.

Plagnes, V., Causse, C., Genty, D., Paterne, M., and Blamart, D.: A discontinuous climatic record from 187 to $74 \mathrm{ka}$ from a speleothem of the Clamouse Cave (south of France), Earth Planet. Sc. Lett., 201, 87-103, 2002.

Randall, D. A., Wood, R. A., Bony, S., Colman, R., Fichefet, T., Fyfe, J., Kattsov, V., Pitman, A., Shukla, J., Srinivasan, J., Stouffer, R., Sumi, A., and Taylor, K.: Climate Models and Their Evaluation, in: Climate Change 2007: The Scientific Basis. Contribution of Working Group 1 to the Fourth Assessment Report of the Intergovernmental Panel on Climate Change, edited by: Solomon, S., Qin, D., Manning, M., Chen, Z., Marquis, M., Averyt, K., Tignor, M., and Miller, H., http://www.ipcc. ch/publications_and_data/ar4/wg1/en/ch8.html, last access: October 2012, Cambridge University Press, Cambridge, UK and New York, NY, USA, 2007.

Riechelmann, D. F. C.: Aktuospeläologische Untersuchungen in der Bunkerhöhle des Iserlohner Massenkalks (NRW/Deutschland): Signifikanz für kontinentale Klimaarchive, Phd thesis, RuhrUniversity Bochum, 2010.

Riechelmann, D. F. C., Schröder-Ritzrau, A., Scholz, D., Fohlmeister, J., Spötl, C., Richter, D. K., and Mangini, A.: Monitoring Bunker Cave (NW Germany): A prerequisite to interpret speleothem isotopic and geochemical time series from this site, J. Hydrol., 409, 682-695, 2011.

Rimbu, N., Lohmann, G., Lorenz, S. J., Kim, J.-H., Schneider, R. R.: Holocene climate variability as derived from alkenone sea surface temperature and coupled ocean-atmosphere model experiments, Clim. Dynam., 23, 215-227, 2004.
Roeckner, E., Bäuml, G., Bonaventura, L., Brokopf, R., Esch, M., Giorgetta, M., Hagemann, S., Kirchner, I., Kornblueh, L., Manzini, E., Rhodin, A., Schlese, U., Schulzweida, U., and Tompkins, A.: The Atmospheric General Circulation Model ECHAM5, Part I: Model Description, Technical Report, MPIReport, Max Planck Institute for Meteorology, Hamburg, 1-140, 2003.

Roeckner, E., Brokopf, R., Esch, M., Giorgetta, M., Hagemann, S., Kornblueh, L., Manzini, E., Schlese, U., and Schulzweida, U.: Sensitivity of simulated climate to horizontal and vertical resolution in the ECHAM5 atmosphere model, J. Climate, 19, 37713791, 2006.

Scholz, D., Mühlinghaus, C., and Mangini, A.: Modelling the evolution of $\delta^{13} \mathrm{C}$ and $\delta^{18} \mathrm{O}$ in the solution layer on stalagmite surfaces, Geochim. Cosmochim. Acta, 73, 2592-2602, doi:10.1016/j.gca.2009.02.015, 2009.

Sundqvist, H. S., Seibert, J., and Holmgren, K.: Understanding conditions behind speleothem formation in Korallgrottan, northwestern Sweden, J. Hydrol., 347, 13-22, 2007.

Thornthwaite, C. W. and Mather, J. R.: Instructions and tables for computing potential Evapotranspiration and the water balance, Publications in Climatology, 10, 3, 1957.

Tomozeiu, R., Busuioc, A., and Stefan, S.: Changes in seasonal mean maximum air temperature in Romania and their connection with large-scale circulation, Intern, J. Climate, 22, 1181-1196, 2002.

Tomozeiu, R., Stefan, S., and Busuioc, A.: Winter precipitation variability and large-scale circulation patterns in Romania, Theor. Appl. Clim., 81, 193-201, 2005.

Tremaine, D. M., Froelich, P. N., and Wang, Y.: Speleothem calcite farmed in situ: Modern calibration of $\delta^{18} \mathrm{O}$ and $\delta^{13} \mathrm{C}$ paleoclimate proxies in a continuously-monitored natural cave system, Geochim. Cosmochim. Acta, 75, 4929-4950, 2011.

Trigo, M. R., Osborn, T. J., and Corte-Real, J. M.: The North Atlantic Oscillation inuence on Europe: climate impacts and associated physical mechanisms, Clim. Res., 20, 9-17, 2002.

Uppala, S. M., Kallberg, P. W., Simmons, A. J., Andrae, U., da Costa Bech Told, V., Fiorino, M., Gibson, J. K., Haseler, J., Hernandez, A., Kelly, G. A., Li, X., Onogi, K., Saarinen, S., Sokka, N., Allan, R. P., Andersson, E., Arpe, K., Balmaseda, M. A., Beljaars, A. C. M., van de Berg, L., Bidlot, J., Bormann, N., Caires, S., Chevallier, F., Dethof, A., Dragosavac, M., Fisher, M., Fuentes, M., Hagemann, S., Holm, E., Hoskins, B. J., Isaksen, L., Janssen, P. A. E. M., Jenne, R., McNally, A., Mahfouf, J. F., Morcrette, J. J., Rayner, N. A., Saunders, R. W., Simon, P., Sterl, A., Trenberth, K. E., Untch, A., Vasiljevic, D., Viterbo, P., and Woollen, J.: The ERA-40 re-analysis, Q. J. Roy. Meteorol. Soc., 131, 2961-3012, 2005.

Van Breukelen, M. R., Vonhof, H. B., Hellstrom, J. C., Wester, W. C. G., and Kroon, D.: Fossil dripwater in stalagmites reveals Holocene temperature and rainfall variation in Amazonia, Earth Planet Sc. Lett., 275, 54-60, 2008.

Varma, V., Prange, M., Merkel, U., Kleinen, T., Lohmann, G., Pfeiffer, M., Renssen, H., Wagner, A., Wagner, S., and Schulz, M. Holocene evolution of the Southern Hemisphere westerly winds in transient simulations with global climate models, Clim. Past, 8, 391-402, doi:10.5194/cp-8-391-2012, 2012. 
Vollweiler, N.: COMNISPA - ein präzise datiertes Klima-Archiv aus holozänen alpinen Stalagmiten, Phd thesis, Ruprecht-KarlsUniversität, Heidelberg, 2010.

Vollweiler, N., Scholz, D., Mühlinghaus, C., Mangini, A., and Spötl, C.: A precisely dated climate record for the last $9 \mathrm{kyr}$ from three high alpine stalagmites, Spannagel Cave, Austria, Geophys. Res. Lett., 33, L20703, doi:10.1029/2006GL027662, 2006.

Wackerbarth, A.: Towards a better understanding of climate proxies in stalagmites - Modelling processes from surface to cave, Dissertation, Ruprecht-Karls-Universität, 2012.

Wackerbarth, A., Scholz, D., Fohlmeister, J., and Mangini, A.: Modelling the $\mathrm{d} 18 \mathrm{O}$ value of cave drip water and speleothem calcite, Earth Planet. Sc. Lett., 299, 387-397, 2010.

Wang, Y. J., Cheng, H., Edwards, R. L., An, Z. S., Wu, J. Y., Shen, C.-C., and Dorale, J. A.: A High-Resolution Absolute-Dated Late Pleistocene Monsoon Record from Hulu Cave, China, Sience, 294, 2345-2348, 2001.

Wanner, H.: North Atlantic Oscillation - Concepts and Studies, Surv. Geophys., 22, 321-382, 2001.

Wanner, H., Beer, J., Bütikofer, J., Crowley, T. J., Cubasch, U., Flückiger, J., Goosse, H., Grosjean, M., Joos, F., Kaplan, J. O., Küttel, M., Müller, S. A., Prentice, C., Solomina, O., Stocker, T. F., Tarasov, P., Wagner, M., and Widmannm, M.: Mid- to Late Holocene climate change: an overview, Quaternary Sci. Rev., 27, 1791-1828, 2008.
Wei, W. and Lohmann, G.: Simulated Atlantic Multidecadal Oscillation during the Holocene, J. Climate, 25, 6989-7002, doi:10.1175/JCLI-D-11-00667.1, 2012.

Werner, M., Langebroek, P. M., Carlsen, T., Herold, M., and Lohmann, G.: Stable water isotopes in the ECHAM5 general circulation model: Towards high resolution isotope modelling on a global scale, J. Geophys. Res., 116, D15109, doi:10.1029/2011JD015681, 2011.

Winterhalder, S.: Ein praezise datierter Multiproxyrecord des Spaetholozaens aus einem suedeuropaeischen Stalagmiten (Closani-Hoehle, Rumänien), master thesis, Ruprecht-KarlsUniversitaet Heidelberg, 2011.

Wurth, G., Niggemann, S., Richter, D. K., and Mangini, A.: The Younger Dryas and Holocene climate record of a stalagmite from Hölloch Cave (Bavarian Alps, Germany), J. Quatern. Sci., 19, 291-298, 2004. 